\title{
The capitalization of operating leases: Analysis of the impact on the IBEX 35 companies
}

\author{
Francisca Pardo iD, Begoña Giner (iD \\ Universitat de València (Spain) \\ francisca.pardo@uv.es,begona.giner@uv.es
}

Received September, 2017

Accepted April, 2018

Versión en español

\section{Abstract}

Purpose: This paper analyzes the consequences of the change in the accounting rules about operating leases in the companies and users of financial information.

Design/methodology: We use the constructive capitalization method to estimate the liabilities and leased assets and perform an ex ante analysis of the regulatory impact in the IBEX 35 non-financial companies. Non-parametric tests are employed to examine the effect on certain ratios, and through a multivariate regression we investigate the business characteristics that explain the variation of EBITDA.

Findings: The ratios under study are significantly affected by the capitalization of operating leases. The explanatory analysis shows that larger companies, which have a higher market valuation and belong to the retail sectors are the ones with a greater increase in EBITDA.

Research limitations/implications: The sample size is small, which implies some caution in the generalization of the results. Certain hypotheses have been introduced to apply the constructive method, although the sensitivity tests confirm that the results are robust.

Practical implications: In certain cases, to avoid non-compliance with restrictions, particularly in debt contracts, contract renegotiations should be initiated. The constructive method yields liabilities and assets significantly smaller than other simpler methods (such as the factor method), so these results can be a relief for certain non-sophisticated users.

Social implications: Investors, shareholders and lenders, and other users will have more transparent information, which should improve their decision-making.

Originality/value: The study of the impact on the magnitudes of the balance sheet and the financial ratios is complemented with a descriptive analysis, which takes into account the industry, and with the modeling of the explanatory factors of the change in EBITDA.

Keywords: Operating leases, IFRS 16, Constructive capitalization method, Financial ratios, Accounting standard impact

Jel Codes: G32, M41, M48 


\section{Introduction}

The accounting standards dealing with leases have undergone significant changes over the years, with the most recent ones having been carried out in 2016 with the approval of the International Financial Reporting Standard (IFRS) 16 (IASB, 2016a) and the Accounting Standards Update (ASU) No. 2016-02 (Topic 842) by the International Accounting Standards Board (IASB) and the Financial Accounting Standards Board (FASB), respectively. These standards, although not identical, fundamentally agree that all lease contracts must be included as assets and liabilities on the balance sheet. It is a change that, judging by the concerns that mainly the affected firms have expressed before its approval, could have a considerable economic impact. Given that, according to Regulation (EC) 1606/2002 of the European Parliament and of the Council regarding the application of international accounting standards, once these standards are accepted by the European Commission (EC) they are mandatory for the consolidated accounts of the firms listed in the European Union (EU), in this work we are going to focus on IFRS 16: "Leases". This standard was adopted in the last quarter of 2017 and will come into force in 2019. In Spain it is common practice to align the local regulations - General Accounting Plan (GAP) and resolutions of the Institute of Accounting and Auditing (Instituto de Contabilidad $y$ Auditoria de Cuentas - ICAC) — to those stipulated in the IFRS, which suggests that the new standard could have a cascading effect and provoke changes that affect other firms and financial statements. In this regard, Molina and Mora (2015, p.111) note that: "There is also the belief that such a radical change of model may end up moving to the national regulations and to smaller-sized entities that are not listed on the stock markets."

In this paper we examine the impact of IFRS 16 on the financial statements of a sample of Spanish firms, with the aim of understanding how certain key accounting metrics used to judge their financial situation may be altered. Likewise, we analyse the characteristics of the firms that may be most affected by the regulatory change.

The great opposition to this accounting standard can be demonstrated by its complex gestation. The due process of IASB standards involves a series of steps, which necessarily include the publication of at least one exposure draft (ED). In this case, in addition, a discussion paper (DP) (IASB, 2009) was issued beforehand and two drafts were also issued (IASB, 2010, 2013). Moreover, these documents must be submitted to public opinion so that interested parties can make suggestions and comments. More than 1,700 letters were received in response to the various documents referring to this project, which exceeds the number normally sent in other cases. The regulatory process also requires an analysis of the expected effects of the accounting standard. In 2016, the analysis of this project was published, whose findings highlight the nearly three trillion dollars of payment commitments for leasing that listed firms, that use IFRS or US GAAP, do not include on the balance sheet, but following the rules currently in force disclose in the notes to the financial statements (IASB, 2016b). The extent to which their recognition on the balance sheet could have economic consequences and affect debt and remuneration contracts, among others, as well as improve the decisions of investors, is the question that underlies this work.

Based on the manually collected information that IBEX 35 firms provide in their notes on payment commitments for operating leases, we conduct an ex ante analysis of the application of IFRS 16. To this end, taking into account the information disclosed and introducing certain hypotheses, we use the constructive method to simulate the impact of the new standard about capitalizing operating leases. We verify whether the changes in a series of financial metrics and ratios, some of which are frequently included as restrictions in debt contracts (covenants), are statistically significant. The results suggest that the new regulations will lead to significant changes in financial data, although there are differences between firms in different industries; however, it seems that the impact will be less than that suggested in some recent international studies (EFRAG, 2016; IASB, 2016b; PwC, 2016). This can have important effects on some contracts as long as: i) they were not taken into account when negotiating the covenants, and ii) they are not reviewed in light of the new standard. However, given the arrangements that exist when using certain ratios derived from financial metrics, it is possible that restrictions will be breached in certain cases, which would, without doubt, entail non-negligible economic effects. Furthermore, through a multivariate analysis we examine the aspects that explain the impact of the standard, and we focus on its impact on an accounting measure frequently used by financial analysts: EBITDA 
(earnings before interest, taxes, depreciation and amortization), which, unlike the previously mentioned ones, improves upon the application of the new standard. The results reveal that the largest firms, which have a higher valuation in the market and belong to the retail industries, see the greatest improvement in this indicator. These results contribute to increasing the knowledge on how the accounting change will affect Spanish firms and how to avoid misunderstandings about its implications. Indeed, as a consequence of the new accounting standard, firms do not "worsen" or "improve" their economic-financial situation, but rather the information should provide a more transparent image of the firm, which should result in better decisions with respect to investment and financing. In addition, the disadvantages of using heuristic methods are noted, given that, although they are simpler, they can lead to a greater error.

In order to have a better idea of the regulatory change, in this paper we first discuss the difficulties of the approval process of IFRS 16, and then present the main developments in the accounting treatment of leases. Next, the conclusions of the studies that have analysed the impact of the change are presented. The work continues with an empirical part in which the analysis of the regulatory change on the IBEX 35 firms is addressed and, lastly, the conclusions of the work are laid out in the final section.

\section{The development of the leases project}

Not only Spanish GAP, but also the international and US accounting standards in force -IAS 17 (IASC, 1997) and Statement of Financial Accounting Standard (SFAS) 13 (FASB, 1976), renamed Accounting for leases, ASC Topic 840, respectively - distinguish between finance and operating leases, and, based on the transfer of the risks and rewards inherent in the ownership of the asset, establish two differentiated procedures. If these are transferred, the lease is classified as finance, giving rise to the recognition of an asset and a liability on the balance sheet. Otherwise, the lease is considered operating and does not give rise to recognition on the balance sheet but is reflected as an expense in the income statement when it is accrued; in addition, information must be provided in the notes to the financial statements on the payment commitments.

To the extent that operating leases do not penalise debt ratios and usually lead to greater profitability, firms prefer to classify lease contracts as operating leases. This has led, for example, to rating agencies, such as Standard \& Poor's and Moody's, developing models to capitalize off-balance-sheet leases. The question is whether they are correct in the adjustments, and if other users are aware of the unrecognized debts. In this regard, Mr Cooper, a member of the IASB at that time, warned about the magnitude of the figures finally recognized, that is, about the debt that eventually emerges, since it is not obvious that the same rigour or the same critical judgment is imposed on the figures disclosed as on those included in the main financial statements, specifically referring to the recognition of extensions in the contract and cancellation options. As a consequence, it is possible that different figures will be recognized than those suggested by the disclosed leases (Cooper, 2017).

Thus, in order to avoid adhoc contracts and confusion over the magnitude of existing debts, both the IASB and the FASB considered developing a project that would eliminate the differentiation. This project began in 2006 and was under taken within the framework of the convergence project between the two institutions that followed the 2002 Norwalk Agreement. However, given that in 2013 the convergence project was abandoned, it is not surprising that finally two non-identical, albeit similar, standards that require the capitalization of all leases have been produced.

The IASB, faithful to the DP (IASB, 2009) and ED/2010/9 (IASB, 2010), understands that all contracts must be capitalized and give rise to the recognition of interest expense (decreasing) and depreciation expense of the asset (normally constant). However, the FASB, in line with the ED/2013/6 (IASB, 2013), differentiates between two categories of leases, which it calls finance and operating, based on the consumption of the asset benefits that the lessee expects to make. If the lessee expects to consume a significant part of them, the lease is finance; otherwise it is operating. Only in the former is the depreciation of the asset distinguished from the financial charge in the income statement, the sum of both decreasing, while in operating leases the expense is constant. However, in both cases the right-of-use asset and the liability are recognized on the balance sheet. 


\section{The regulatory model according to IFRS 16}

It is important to note that, unlike what is currently established in IAS 17, IFRS 16 requires for the identification of a lease contract, in addition to the right to use an identified asset, the right to control the use of that assset. The lessee must recognize an asset, the right-of-use asset, which represents its right to use the underlying leased asset, and a lease liability, which represents its obligation to make the payments derived from it. However, the new standard allows the lessee not to apply this general criterion in two cases: short-term leases and those of low-value assets. A short-term lease is that, at the commencement date, has a lease term of 12 months or less, and does not contain a purchase option. With regard to leases of low-value assets(for example: tablets and personal computers, small items of office furniture and telephones), the value of the underlying asset must be considered in terms of its value when it is new, regardless of the age of the leased asset. Neither of these two exceptions is contemplated in the current IAS 17.

If the same contract includes, in addition to a lease, other components (for example, maintenance services or other services), in principle they must be separated and accounted for independently (following the corresponding standard according to their nature). However, IFRS 16 allows for the components not to be separated by type of underlying asset, and, instead, accounting for everything as a single lease (IASB, 2016a, para. 15).

In general, the accounting treatment of leases under IFRS 16 is similar to that established by the current rules for finance leases, except for a few differences. Thus, the lease liability includes the present value of the future lease payments, which are basically: fixed payments, including the so-called "in substance" fixed lease payments (less any incentive that will be received from the lessor); variable lease payments referenced to an index or to an interest rate (for example, to the CPI or the Euribor); amounts that are expected to be paid under a residual value guarantee; the exercise price of a purchase option (if the lessee has reasonable certainty that it will be exercised); payments for penalties for terminating a lease (if the lease term suggests that the lessee will exercise the option to terminate it). However, in IAS 17, contingent lease payments are not included in the initial value of the liability, which may be a relevant difference since these payments are currently recognized in the operating income regardless of the classification of the lease.

Regarding the implicit interest rate of the lease, given the difficulties in gathering the information for its determination, as $\mathrm{Mr}$ Scott, a member of the IASB, points out, it is probable that many firms use the alternative of the incremental interest rate (Scott, 2017).

As for the right-of-use asset, it is initially valued at the initial amount of the liability plus any payment made prior to the start of the lease contract (less incentives, if any), the direct costs incurred by the lessee and an estimate of costs of dismantling and removing the underlying asset. Subsequently, the asset must be amortized using a systematic and rational method (generally linear), and, additionally, its possible impairment should be recognized, if applicable. Since the effective interest rate method is applied to the liability, the recognition of lease expenses is not linear (as is generally the case in current operating leases) but decreasing.

In addition, the lessee must remeasured the lease liability in some cases such as: i) changes in the amount to be paid under a residual value guarantee, ii) changes in the lease payments due to variations in an index or the interest rate used to determine said payments, iii) changes in the lease terminitially established as a consequence of a change in the non-cancellable period thereof, and iv) changes in the valuation of the exercise price of an option to purchase (IASB, 2016a, para. 40-43). The first two changes must be calculated using the original interest rate, while for the last two cases, the new cash flows must be discounted using a new interest rate, revised on the date of change. The remeasurements are treated as adjustments in the value of the asset, unless its value is zero, in which case any remaining amount must be allocated to the income statement.

With respect to the presentation in the financial statements, the right-of-use asset and the lease liability must be included on the balance sheet separately from other assets and liabilities, but it may also not be done and this peculiarity disclosed in the notes. In the income statement, as in IAS 17 for finance leases, the lessee must present the interest expense derived from the lease liability separately from the depreciation of the right-of-use 
asset. Thus, interest expense is a financial expense, while depreciation is an operating expense. In the statement of cash flows, cash payments for the principal of the lease liability should be classified as a financing activity, while cash payments for the interest charge of the lease liability should be presented in consistence with other payments of interest charges. However, short-term lease payments, payments for leases of low-value assets and variable lease payments not included in the valuation of the lease liability must be included in the operating activities in the income statement, and they are considered operating activities in the statement of cash flows.

\section{Effects of the lease capitalization in the previous literature}

The pioneering work of Nelson (1963), produced before any rule required the capitalization of leases, was followed by those that analysed the impact of the US standard that obliged the capitalization of finance leases (Imhoff \& Thomas, 1988), but other later works, also referring to US, focused on the operating lease capitalization (Imhoff, Lipe \& Wright, 1993; Mulford \& Gram, 2007). This approach has also been followed in other countries, such as the UK by Beattie, Edwards and Goodacre (1998) and Goodacre (2003), New Zealand by Bennett and Bradbury (2003), Canada by Durocher (2008), Germany by Fülbier, Silva and Pferdehirt (2008), Spain by Fitó, Moya and Orgaz (2013), Barral, Cordobés and Ramírez (2014) — which also considers the UK-, Giner and Pardo (2017) and Gill de Albornoz, Rusanescu and Cabedo (2017). To this end, the amount of offbalance liabilities is estimated, which are incorporated into the financial statements as if they were recognized by the firms. The general conclusion is that the ratios (particularly those of the balance sheet and, most importantly, those of leverage) are affected, as well as some profitability ratios, although these papers detect important differences between firms and between industries. It is precisely this worsening of financial indicators that helps us to understand the strong reluctance of firms to capitalize leases in general, and operating leases in particular, as has been shown in the comment letters sent throughout the due process.

The PwC study on the impact of the capitalization of operating leases, referring to 3,199 listed firms that use IFRS, reveals an average increase in debt of $21 \%$ and EBITDA of $11 \%$ in the EU. Regarding the debt ratio (total debt divided by EBITDA) it goes from 1.55 to 1.78, while solvency decreases from $46 \%$ to $41.6 \%$. It is important to note that the impact differs between industries, being especially noteworthy in the retail, airline, professional services and health industries (PwC, 2016). EFRAG published a study in 2016 on the impact in the EU, based on the largest firms by market capitalization and with the highest volume of operating leases (EFRAG, 2016). Essentially, it concludes that the change represents an average increase in the level of debt in relation to the financial debt of $4 \%$ (the energy industry, at 26\%, being the most affected), although if the financial sector is excluded, the increase reaches 16\%, while equity is reduced by $0.6 \%$ (by $0.9 \%$ if the financial industry is excluded). Also in 2016, the effects analysis of the IASB was made public; based on 1,022 firms that apply IFRS, of which 348 are European, it concluded that the increase in the amount of debts is 1,661.8 billion dollars, which represents $5.4 \%$ of the total assets, which reaches $20 \%$ in the air, retail, transport and leisure industries (IASB, 2016b). It should be noted that, with the exception of the EFRAG study, the other analyses exclude the financial sector.

On the other hand, through a survey to 284 executives to find out their views on how the new way of accounting for operating leases may affect firms, Deloitte (2011) concludes that the rule may have a significant effect and firms do not seem to be prepared. $68 \%$ of the respondents consider that they will see their leverage ratios increased (specifically debt over equity), which, according to $40 \%$ of the respondents, will make it difficult to obtain financing, will reduce the lease term, and $25 \%$ consider that it will make lessees prefer purchasing over leasing. Other ratios they were asked about are ROA (return on assets) and interest coverage, and according to $49 \%$ and $40 \%$, respectively, the effect will also be relevant. They were also questioned about the impact on operating margins and EBITDA, with $37 \%$ and $41 \%$ responding, respectively, that the impact will be material.

As indicated above, the different way of accounting for finance and operating leases has clear implications for the apparent financial situation of the firm, which has likely encouraged firms to design adhoc contracts to avoid recognition of leases (Imhoff \&Thomas, 1988; Duke, Hsieh \& Su, 2009; Beatty, Liao \& Weber, 2010; Bryan, Lilien \& Martin, 2010; Dechow, Ge, Larson \& Sloan, 2011). Abdel-Khalik (1981) is one of the first authors to point out that firms opt for operating leases to avoid breaking the restrictions established in debt contracts. 
Indeed, certain financial ratios are often included in debt agreements as restrictions or covenants (Beneish \& Press, 1993; Nikolaev, 2010; Franz, HassabElnaby \& Lobo, 2014).

As has been shown, the application of IFRS 16 will alter to a greater or lesser extent the accounting figures and financial ratios; however, if this is going to provoke breaches in the covenants, which require the renegotiation of the loan conditions, among other contractual agreements, it is an aspect that cannot be predicted without having a precise knowledge of the terms of the contracts and their restrictions. In the aforementioned survey $44 \%$ of the executives interviewed feel that it will have an impact on these restrictions, although $32 \%$ believe the contrary (Deloitte, 2011). Faced with these divided opinions, we should also raise the opinion expressed by IASB staff in the effects analysis document (IASB, 2016b), according to which there should be no impact on the cost of debt and covenants, since it is thought that there will be renegotiations. On the other hand, Demerjian (2011) and Paik, van der Laan Smith, Lee and Yoon (2015) argue that the off-balance-sheet debts are already taken into account in the negotiations prior to setting the covenants, so that a possible regulatory change should be innocuous. The IASB document also agrees that there may be a change in the form of financing, purchase versus leasing, in those cases in which the reason for having an operating lease was to remove it from the balance sheet.

In short, after the application of IFRS 16, firms will have more debts and assets on the balance sheet, which will generally entail a higher value for the leverage ratio and perhaps a reduction in economic profitability. Faced with the above, which suggests an apparent worsening of the business situation (we must not forget that the payment commitments, although not recognized, do exist), one must counter with the improvement in the EBITDA that the new treatment of operating leases entails. Indeed, this indicator does not include financial expenses or depreciation among its components, so replacing the lease expense with depreciation and interest will result in a higher EBITDA.

\section{Empirical analysis}

\subsection{Sample}

The initial sample is composed of the firms that made up the IBEX 35 in 2014, and that disclosed information about operating leases in their notes to the financial statements. These firms have been frequently considered in prior studies, since they represent a collective in which some of the most relevant issues related to accounting and financial information can be identified (Ortiz \& Marín, 2014; Reverte, 2009, 2016). We exclude financial institutions and insurance firms, which, in addition to being common in the accounting literature given the different interpretation of financial ratios, are especially frequent when analysing the impact of the capitalization of operating leases. In fact, as indicated above, they are only included in the study by EFRAG (2016). It should be borne in mind that the inclusion of the financial and insurance industries may underestimate the relative impact, since in these entities, in addition to being large, they tend to have few material operating leases. Additionally, it is necessary to eliminate those firms that do not report operating leases in the notes, so that the sample is reduced to 20 firms. The simulation study has been done for the four-year period between 2010 and 2013 , inclusive.

The information necessary to estimate the operating leases has been obtained manually from the notes, while the additional financial and market data are from the Sistema de Análisis de Balances Ibéricos (SABI) database. As required by IAS 17 , the minimum future payments for operating leases, categorisedas those corresponding to one year, between one and five years and after five years, must be disclosed. These data allow us to know a first approximation of the amount of unrecognized debt, but given that the figure is not discounted, it is overvalued.

In order to obtain the value of the unrecognized debt, it is necessary to update the future payments. To do this, the constructive capitalization method has been used, which shows the effect of capitalization on assets and liabilities, and also provides the impact on equity. This method was developed by Imhoff, Lipe and Wright (1991) and has been applied frequently in this literature (Imhoff et al., 1993; Imhoff, Lipe \& Wright, 1997; Durocher, 2008; Fülbier et al., 2008; Fitó et al., 2013; Giner \& Pardo, 2017). Under this method opera ting lease agreement 
are measured as if they were finance leases from the beginning. In the following subsection we explain how this method operates.

It is also common to use the factor method, which entails multiplying by a coefficient (usually 8 ) the lease payments that are included in the income statement (Imhoff et al., 1993; Ely, 1995; Beattie, Goodacre \& Thomson, 2000; Bennett \& Bradbury, 2003). In such a case, assets and liabilities increase equally, without any impact on equity. This procedure is used as a sensitivity analysis in this work.

\subsection{Constructive capitalization method}

The implementation of this method requires the introduction of certain simplifying hypotheses. Following Imhoff et al. (1991) and Fülbier et al. (2008), we assume the following: 1) at the beginning of each lease agreement, the book value of the leased asset is equal to the value of the lease liability; 2) at the end of the lease, the book values of assets and liabilities are zero; 3) the asset is depreciated using the straight-linemethod; 4) all lease payments are made at the year-end; 5) the lease payments are constant; and 6) minimum lease payments are divided into five categories of contracts with different lifetimes (from one year to five years or more).

Since the future minimum operating lease payments $(M O L P)$ are not disclosed separately by year (except for the first), it is necessary to isolate payments per year. For payments of two to five years, a geometric degression model is assumed in which lease payments decrease at a constant rate; the payment of any year $\left(M O L P_{t+1}\right)$ is obtained by multiplying the payment of the previous year $\left(M O L P_{t}\right)$ by the degression factor $(d f)$, as follows:

$$
M O L P_{t+1}=M O L P_{t} \times d f
$$

so the degression factor is obtained from the following expression:

$$
M O L P_{2-5}=M O L P_{1} \times d f^{1}+M O L P_{1} \times d f^{2}+M O L P_{1} \times d f^{3}+M O L P_{1} \times d f^{4}
$$

or what is the same:

$$
M O L P_{2-5}=\sum_{(t=1)}^{4} M O L P_{1} \mathrm{x} d f^{t}
$$

The above expression produces decreasing lease payments, which is consistent with having several lease agreements with different lengths(and not just one contract). Taking into account these aspects, and following Fülbier et al. (2008), we divide the MOLP into five categories of contracts with different remaining lifetimes (one year up to five years or more) and we obtain the present value of each group. To separate them we calculate the difference between the MOLP in two consecutive years $\left(M O L P_{t}-M O L P_{t+1}\right)$, which represents the contract that ends each year. In the last period of annual payments, we divide the aggregate payment after year five into equal annual payments to the fifth group $\left(M O L P_{5+} / M O L P_{5}\right)$, which allows us to approximate the number of years of payments remaining to be make. This is consistent with the general assumption that lease agreement payments are constant. We must point out that we use the information provided in the notes to the greatest extent possible, so when the firm discloses the annual disaggregated payments, we use this information. For those firms that disclose MOLP in shorter periods, we have grouped the payments in the standard periods in order to implement the method in a uniform manner.

Once the future payments have been estimated, it is necessary to use a discount rate to determine the present value. Although the most appropriate value is the one implicit in the leases, only two firms in the sample provide this information. After analysing the different possibilities offered by the literature: establish a fixed interest rate (Imhoff et al., 1991), use the one obtained by dividing the financial expenses by the earnings before interest and taxes (hereinafter, EBIT) by adding a risk-free rate (Fitó et al., 2013), use the one that results from dividing financial expenses by the financial debt (Imhoff et al., 1991, 1997) or use the discount rate applied to provisions (Fülbier et al., 2008), we have opted for the latter; it captures the peculiarities of the firm and was available in most of the firms considered. As these authors do, for the five firms for which we did not have this information, 
we have applied the median of the rest of the firms that do reveal this rate $(4.36 \%)$. After making the appropriate calculations, the applied discount rates range between $2.80 \%$ and $8.51 \%$.

Regarding the asset value, although it is equal to the liability at inception of the lease, at any other time it differs. Thus, the value of the asset is a function of the present value of the MOLP at the beginning of the lease ( $\left.\mathrm{PV}_{\text {TL }}\right)$ and the relationship between the remaining life of the lease $(R L)$ and its total life (TL):

$$
\text { Asset value }=P V_{\mathrm{TL}} \times \frac{\mathrm{RL}}{\mathrm{TL}}
$$

Given that the lease liability at the end of the year is equal to the present value of the MOLP during the remaining useful life $\left(P V_{R L}\right)$, the relationship of any leased asset with the corresponding liability at any time during the contract period is determined by:

$$
\frac{R L}{T L} \times \frac{P V_{T L}}{T L_{R L}}
$$

or what is the same:

$$
\frac{R L}{T L} \times \frac{1-(1+i)^{-T L}}{1-(1+i)^{-R L}}
$$

Since we do not have the total MOLP, we apply the previous formula and use the estimated interest rate. In addition, since the total life of the lease is not disclosed in the financial statements, in order to estimate the amount of assets not recorded when applying the constructive method, we assume that the already expired proportion of the lease life $\left(V_{R} / V_{T}\right)$ is $50 \%$, in line with previous works (Ely, 1995; Bennett \& Bradbury, 2003; Durocher, 2008; Fülbier et al., 2008). We must emphasize that this assumption has a minimal effect on the income figure, since the sum of interest and depreciation is very similar to the lease expense. However, in a sensitivity analysis we also consider 60\%, like Fülbier et al. (2008) and Fitó et al. (2013), among others.

Capitalization has an impact on the deferred tax, and its amount is obtained by multiplying the difference between the asset and the liability by the estimated tax rate. The difference between both amounts (the difference between the asset and the liability minus the deferred tax decrease) is the amount by which the equity will be reduced. The tax rate is obtained by dividing the corporate tax expense by the earnings before taxes (herein after EBT) of the corresponding year. In the event that the EBT is negative or in the absence of tax expense, the tax rate that has been used is the tax rate applied in the nearest fiscal year.

\subsection{Impact of the capitalization of operating leases}

Before calculating the new ratios, the value of the assets, liabilities and equity have been adjusted by the capitalization of operating leases. Table 1 shows the amount of the undiscounted operating lease liabilities (in column 1) and once discounted by the constructive method (in column 2) for each of the analysed years. The difference between both values depends on the hypothesis assumed on the interest rate, among other aspects. Comparing the data in columns 1 and 2, it can be verified that it is not a negligible difference, since the undiscounted figures are around 30\% higher than those resulting from applying the constructive method (reaching 36\% in 2013).

As shown in column 2, in any of the years, the total amount of off-balance-sheet debts would be around 20 billion euros, which is an aggregate $4.81 \%$ increase compared to the liabilities recognized on the balance sheet (non-tabulated data), a higher figure than that indicated by the EFRAG (2016), which is $1.3 \%$ (although it must be borne in mind that this figure includes the financial industry, which in our sample has been excluded). Comparing the increase in debt with the assets, as the IASB does, in our analysis we obtain $3.3 \%$ (non-tabulated data), less than the $5.4 \%$ presented in that report (IASB, 2016b). 
Column 4 of Table 1 includes the finance lease debt recognized on the balance sheet (also obtained manually from the notes), in which one can observe that the operating lease liabilities considerably exceed the finance lease liabilities, since the former are more than double the finance leases. Regarding the proportion of finance and operating leases, column 3 shows the percentages per year of the operating lease debt with respect to total lease debt ranging between $65 \%$ and $69 \%$, figures that are similar to the $67 \%$ provided for 2005 by Barral et al. (2014). These data could suggest that this form of financing is preferred precisely because of the possibility it offers to escape from the control exercised by having to appear on the balance sheet. However, it is still significantly below the figure provided in the EFRAG study, which indicates that the volume of operating leases is 8.7 times greater than that of finance leases.

\begin{tabular}{|l|r|r|r|r|r|r|r|}
\cline { 2 - 10 } \multicolumn{1}{c|}{} & Undiscounted OL & Discounted OL & OL/TL & \multicolumn{1}{c|}{ FL } & FL/TL & TL & OL expense \\
\hline $\mathbf{2 0 1 0}$ & $23,688,074$ & $18,713,864$ & $67 \%$ & $9,165,214$ & $33 \%$ & $27,879,078$ & $4,942,991$ \\
\hline $\mathbf{2 0 1 1}$ & $27,276,663$ & $20,979,412$ & $65 \%$ & $11,225,370$ & $35 \%$ & $32,204,782$ & $5,889,192$ \\
\hline $\mathbf{2 0 1 2}$ & $26,952,705$ & $21,321,158$ & $68 \%$ & $9,897,575$ & $32 \%$ & $31,218,733$ & $6,267,043$ \\
\hline $\mathbf{2 0 1 3}$ & $27,042,823$ & $19,860,848$ & $69 \%$ & $9,110,179$ & $31 \%$ & $28,971,027$ & $6,149,995$ \\
\hline Total & $\mathbf{1 0 4 , 9 6 0 , 2 6 5}$ & $\mathbf{8 0 , 8 7 5 , 2 8 3}$ & $\mathbf{6 7 \%}$ & $\mathbf{3 9 , 3 9 8 , 3 3 8}$ & $\mathbf{3 3} \%$ & $\mathbf{1 2 0 , 2 7 3 , 6 2 0}$ & $\mathbf{2 3 , 2 4 9 , 2 2 1}$ \\
\hline
\end{tabular}

Note: OL are the payment commitments for operating leases; FL is the finance lease liabilities; TL is the total lease liabilities. The figures are in thousands of euros.

Table 1. Aggregate amount of operating lease liabilities, finance lease liabilities and total lease liabilities in absolute and relative terms per year

These values are illustrated graphically in Figure 1 in which the consistency in the values in the four years examined is also displayed. We should point out that in this figure the average values of the firms analysed are represented, so the percentages indicated in the solid lines do not coincide with the percentages shown in Table 1 , in which they have been calculated in an aggregate manner.

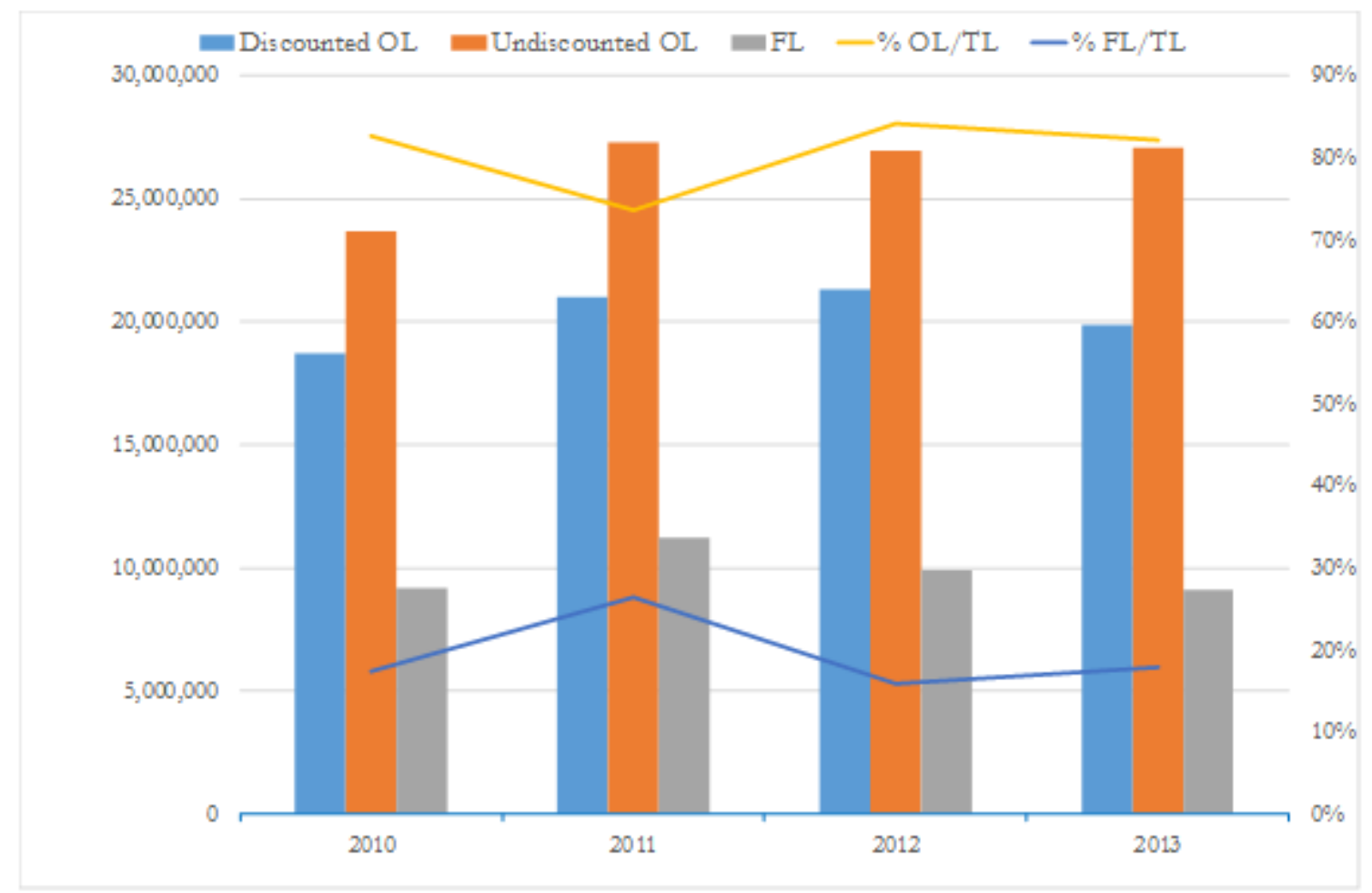

Note: OL are payment commitments for operating leas es; FL is finance lease liabilities; T'L is total lease liabilities. The figures are in thousands of euros.

Figure 1. Absolute and relative values of operating and finance leases per year 
Table 1 also provides other information of interest: the operating lease expense, that is, the change in EBITDA, which, as indicated, improves with the regulatory change. In fact, the last column shows an aggregate annual increase in three of the four years of more than five billion euros in this magnitude, which is $1 \%$ (non-tabulated data) of the value of the aggregate assets.

Table 2 shows the descriptive statistics corresponding to the changes in assets, liabilities and equity resulting from the capitalization of operating leases, as well as the variation in EBITDA compared to total assets. It is observed that the increase in liabilities is $7 \%$ on average with a median of $2.2 \%$, although it has a large standard deviation, and in fact the maximum reaches $67 \%$. The $\mathrm{PwC}$ report documents a $21 \%$ increase in the average debt for the European firms considered (PwC, 2016). The increase in assets is lower, 3.5\% on average and a median of $1.3 \%$, with $21.3 \%$ being the maximum. In terms of equity, the average decrease is $2.3 \%$, while in the median it is only $0.5 \%$, although there are extreme cases, and the largest reduction is $28.3 \%$. The ratio increase in EBITDA divided by total assets shows an average increase of $1.9 \%$ ( $0.9 \%$ median) and reaches a maximum value of $13 \%$. This is again a consequence of the great dispersion in the data, that is, of the different foreseeable impacts of the accounting change at the firm level.

\begin{tabular}{|l|r|r|r|r|r|r|r|r|}
\cline { 2 - 9 } \multicolumn{1}{c|}{} & \multicolumn{4}{c|}{ Variation in absolute terms (thousands of euros) } & \multicolumn{3}{c|}{ Variation in relative terms (\%) } \\
\cline { 2 - 9 } \multicolumn{1}{c|}{} & \multicolumn{1}{c|}{ Assets } & \multicolumn{1}{c|}{ L Liabilities } & \multicolumn{1}{c|}{$\Delta$ Equity } & \multicolumn{1}{c|}{$\Delta$ EBITDA } & $\Delta A / T A$ & $\Delta L / T L$ & $\Delta E / T E$ & $\Delta E B I T D A / T A$ \\
\hline Mean & 888,329 & $1,010,941$ & $-122,612$ & 309,990 & $3.5 \%$ & $7.0 \%$ & $-2.3 \%$ & $1.9 \%$ \\
\hline StdDev & $1,601,073$ & $1,797,423$ & 209,820 & 394,967 & $5.3 \%$ & $14.3 \%$ & $5.0 \%$ & $3.0 \%$ \\
\hline Min. & 445 & 452 & $-1,057,647$ & 474 & $0.02 \%$ & $0.1 \%$ & $-28.3 \%$ & $0.02 \%$ \\
\hline Median & 233,542 & 268,577 & $-20,438$ & 133,000 & $1.3 \%$ & $2.2 \%$ & $-0.5 \%$ & $0.9 \%$ \\
\hline Max. & $8,020,092$ & $8,699,720$ & -7 & $1,663,967$ & $21.3 \%$ & $67.0 \%$ & $-0.0005 \%$ & $13.0 \%$ \\
\hline
\end{tabular}

Note: $\Delta \mathrm{A} / \mathrm{TA}$ is the change in assets by capitalization of the operating leases with respect to total assets; $\Delta \mathrm{L} / \mathrm{TL}$ is the change in liabilities by capitalization of operating leases with respect to total liabilities; $\Delta \mathrm{E} / \mathrm{TE}$ is the change in equity by capitalization of operating leases with respect to total equity; $\triangle \mathrm{EBITDA} / \mathrm{TA}$ is the change in EBITDA by capitalization of operating leases with respect to total assets.

Table 2. Descriptions of the variation by capitalization of operating leases by company

As has been noted before, the methodology used to calculate the amount of off-balance-sheet debts requires the assumption of some hypotheses referring to the interest rate for discounting lease payments and the remaining useful life of the leased asset. In Table 3 we present the descriptive statistics of the liabilities for operating leases with respect to total assets using various scenarios. In the first column they are presented using the discount rate used by each firm for the provisions; in the second column a fixed interest rate of $5 \%$ has been used, and in the third we use 10\%. In the fourth column the initial interest rate has been maintained, however, the hypothesis about the remaining useful life of the asset has been modified in such a way that the Residual Life/Total Life ratio is $60 \%$, instead of $50 \%$, which is used in the columns described above. Finally, in column 5: "Undiscounted" appears the sum of the future payments for operating leases indicated in the notes, while in the last column a simple method has been applied, frequently used in the business world, the factor method. This heuristic procedure consists of multiplying the annual operating lease expense by a multiplier, with eight being the one usually employed in previous works (Imhoff et al., 1993; Ely, 1995; Beattie et al., 2000; Bennett \& Bradbury, 2003). Beattie et al. (2000) echo previous works in which a range between 6.9 and 10.2 is set for leases between 10 and 20 years, so we consider that eight is an acceptable multiplier.

Although the use of one interest rate or another does not affect the descriptive statistics too greatly (in columns 1 to 3), nor does it alter the remaining useful life (in column 4), the other options produce significantly different figures. In particular, applying the factor method, it is concluded that the average increase will be 15.1\% (almost four times more than the constructive one), with a median of $7.1 \%$ ( 5 times more), the maximum being 103.6\% of total assets. It should not be surprising that this method overvalues assets and liabilities, since it also happens in works referring to the USA (Imhoff et al., 1993), the UK (Beattie et al., 2000) and New Zealand (Bennett \& Bradbury, 2003). Another reason for this overstatement is that the term of contracts in our sample (median of 18 years) is lower than in other countries such as the USA. 


\begin{tabular}{|c|c|c|c|c|c|c|}
\hline & $\begin{array}{c}\text { Constructive } \\
\text { method }\end{array}$ & $\begin{array}{c}\text { Constructive } \\
\operatorname{method}(i=5 \%)\end{array}$ & $\begin{array}{c}\text { Constructive } \\
\operatorname{method}(i=10 \%)\end{array}$ & $\begin{array}{l}\text { Constructive method } \\
\qquad\left(V_{R} / V_{T}=\mathbf{6 0} \%\right)\end{array}$ & Undiscounted & $\begin{array}{l}\text { Factor } \\
\text { method }\end{array}$ \\
\hline Mean & $3.9 \%$ & $3.8 \%$ & $3.1 \%$ & $4.0 \%$ & $5.0 \%$ & $15.1 \%$ \\
\hline StdDev & $5.9 \%$ & $5.7 \%$ & $4.7 \%$ & $6.0 \%$ & $7.5 \%$ & $24.2 \%$ \\
\hline Min. & $0.02 \%$ & $0.02 \%$ & $0.02 \%$ & $0.02 \%$ & $0.02 \%$ & $0.2 \%$ \\
\hline Median & $1.4 \%$ & $1.4 \%$ & $1.2 \%$ & $1.4 \%$ & $1.9 \%$ & $7.1 \%$ \\
\hline Max. & $23.1 \%$ & $22.6 \%$ & $19.2 \%$ & $23.3 \%$ & $27.5 \%$ & $103.6 \%$ \\
\hline
\end{tabular}

Note: Constructive method: it means applying a specific discount rate for each company, as explained in section 5.2; Constructive method $(i=5 \%)$ : it means using a fixed interest rate $(5 \%)$; Constructive method $(i=10 \%)$ : it means using a fixed interest rate (10\%); Construction method $\left(V_{R} / V_{T}=60 \%\right)$ : it implies modifying the hypothesis about the remaining useful life of the asset, in such a way that the Residual Life/Total Life ratio is $60 \%$; Undiscounted: it is the sum of the future payments for operating lease disclosed; Factor method: this means multiplying the annual operating lease expense by a factor of 8 .

Table 3. Percentage of estimated operating lease liabilities with different assumptions and methods with respect to total assets

Once the variations derived from the inclusion of the new elements have been computed, in Table 4 we present a series of ratios before and after the capitalization, some of which are frequently taken into account in the covenants included in loan contracts. The first five ratios evaluate the impact on the presentation of the items on the balance sheet (solvency, leverage, debt quality, liquidity, and intensity of investment). In the remaining three, the effect on profitability is considered both from the economic perspective: non-current asset turnover and ROA, as well as financial: ROE (return on equity). Finally, we calculate the market-to-book ratio, which serves as an indicator of the market's valuation of the firm and captures the firm's growth opportunities. The precise calculation method of these ratios is indicated at the bottom of the table.

After obtaining the ratios, we present the medians of the values before and after the capitalization, since this statistic is less affected by the extreme values than the average, and we calculate their relative variation. Finally, in order to determine if the differences of these ratios are statistically significant, we apply the Wilcoxon nonparametric test (having previously verified that the variables do not follow a normal distribution).

\begin{tabular}{|l|r|r|r|r|}
\hline Ratio & Before capitalization & After capitalization & Relative difference & Wilcoxon test \\
\hline Solvency & 1.405 & 1.395 & $-0.65 \%$ & $7.770^{* * *}$ \\
\hline Leverage & 2.472 & 2.529 & $2.31 \%$ & $-7.770^{* * *}$ \\
\hline Debt quality & 0.445 & 0.422 & $-5.37 \%$ & $6.509^{* * *}$ \\
\hline Liquidity & 1.087 & 1.075 & $-1.13 \%$ & $7.770^{* * *}$ \\
\hline Intensity of investment & 0.689 & 0.696 & $1.02^{\%}$ & $-7.770^{* * *}$ \\
\hline Non-current asset turnover & 0.988 & 0.923 & $-6.56 \%$ & $7.770^{* * *}$ \\
\hline ROA & 0.047 & 0.046 & $-2.15 \%$ & $6.777^{* * *}$ \\
\hline ROE & 0.106 & 0.107 & $1.33 \%$ & $-5.823^{* * *}$ \\
\hline Market-to-book & 1.446 & 1.456 & $0.71 \%$ & $-7.673^{* * *}$ \\
\hline
\end{tabular}

Note: Solvency is measured as total assets/total liabilities; Leverage as total liabilities/total equity; Debt quality as short-term liabilities/total liabilities; Liquidity as current assets/current liabilities; Intensity of investment as non-current assets/total assets; Non-current asset turnover as net sales/non-current assets; ROA as EBIT/total assets; ROE as net income/total equity; Market-to-book as market capitalization/total equity. The values of the ratios are the median of the sample companies.

Table 4. Impact of the capitalization of operating leases on financial ratios

As seen in Table 4, all the variations are statistically significant, as happens in Fitó et al. (2013) and Giner and Pardo (2017), among others. The ratios that suffer the most impact are non-current asset turnover, debt quality, followed by leverage and ROA. For the rest, the impact is close to $1 \%$. It should be noted that not all ratios are penalised, since the financial profitability ratio (ROE) and the market-to-book ratio improve $(1.33 \%$ and $0.71 \%$, respectively), ratios that ultimately capture gains for the shareholders. There is also a notable improvement in the debt quality ratio (it decreases by 5.37\%), since most of the debt added to the balance sheet is long-term debt. However, leverage, solvency, liquidity, as well as non-current asset turnover and ROA are penalised (the first increases by $2.31 \%$ and the others are reduced; the impact on non-current asset turnover is $6.56 \%$ and on ROA $2.15 \%$ ). This means that some firms could be forced to renegotiate the conditions of their loans if these ratios 
have been included in the debt contracts without having "frozen" the accounting practices to be taken into account for their calculation; in this case it would be convenient to start conversations as soon as possible to avoid last-minute surprises.

Given that the literature suggests that not all industries will be equally affected by the accounting change (EFRAG, 2016; IASB, 2016b; PwC, 2016), we consider it interesting to make the comparison of the impact by industries. However, as the sample size is small, what we present below is rather an analysis by firm. Based on the classification of the Madrid Stock Exchange: Energy; Construction and manufacturing; Retail goods; Retail services; and Technology, we have calculated the impact as the average variation of the ratios of the firms in each industry, and in Table 5 we present the results. It is not surprising that it is the firms in the retail goods and retail services industries that are most affected by the accounting change, given that, as the previous literature reveals, in these industries this type of contract is widely used. Overall, we must highlight the impact on the leverage and economic profitability ratios (ROA). In the firms of these industries, leverage increases by $25 \%$, given the increase in the volume of recognized debts. In addition, non-current asset turnover and ROA are reduced by approximately $11 \%$ and $7 \%$, respectively, as a consequence of the increase in assets that capitalization implies. However, the impact of capitalization on equity differs between both groups of firms, which affects changes in the solvency ratio, ROE and market-to-book.

\begin{tabular}{|l|r|r|r|r|r|}
\hline Ratio & Energy & $\begin{array}{c}\text { Construction and } \\
\text { manufacturing }\end{array}$ & Retail goods & Retail services & Technology \\
\hline Solvency & $-1.1 \%$ & $-0.5 \%$ & $-10.2 \%$ & $-2.7 \%$ & $-1.4 \%$ \\
\hline Leverage & $2.9 \%$ & $3.1 \%$ & $25.9 \%$ & $25.0 \%$ & $6.0 \%$ \\
\hline Debt quality & $-0.8 \%$ & $-0.7 \%$ & $-7.4 \%$ & $-6.0 \%$ & $-1.7 \%$ \\
\hline Liquidity & $-1.4 \%$ & $-0.8 \%$ & $-9.7 \%$ & $-4.4 \%$ & $-2.6 \%$ \\
\hline Intensity of investment & $0.4 \%$ & $3.4 \%$ & $6.7 \%$ & $3.4 \%$ & $0.7 \%$ \\
\hline Non-current asset turnover & $-1.6 \%$ & $-4.0 \%$ & $-11.8 \%$ & $-10.5 \%$ & $-3.5 \%$ \\
\hline ROA & $-1.1 \%$ & $-1.1 \%$ & $-6.8 \%$ & $-7.6 \%$ & $-2.9 \%$ \\
\hline ROE & $0.7 \%$ & $1.4 \%$ & $1.3 \%$ & $11.2 \%$ & $1.5 \%$ \\
\hline Market-to-book & $0.7 \%$ & $1.4 \%$ & $1.3 \%$ & $11.3 \%$ & $1.5 \%$ \\
\hline
\end{tabular}

Note: Solvency is measured as total assets/total liabilities; Leverage as total liabilities/total equity; Debt quality as short-term liabilities/total liabilities; Liquidity as current assets/current liabilities; Intensity of investment as non-current assets/total assets; Non-current asset turnover as net sales/non-current assets; ROA as EBIT/total assets; ROE as net income/total equity; Market-to-book as market capitalization/total equity. The values of the changes in ratios as a result of capitalization are the median of the sample companies.

Table 5. Average impact of the capitalization of operating leases on financial ratios by industry

Figure 2 captures the impact on EBITDA. Again, the firms in the retail industries are the most affected, although we observe behaviour that is different from that in the retail goods and retail services industries. Non-tabulated data reveal that in the retail goods industry the annual lease expense is much higher than in retail services (mainly due to the firm Inditex), although operating lease debt is not very different in absolute terms, or with respect to the total assets. This means that the impact of the ratio change in EBITDA/total assets implies an increase of $6.7 \%$ in firms in the retail goods industry, compared to $3.4 \%$ in retail services. 


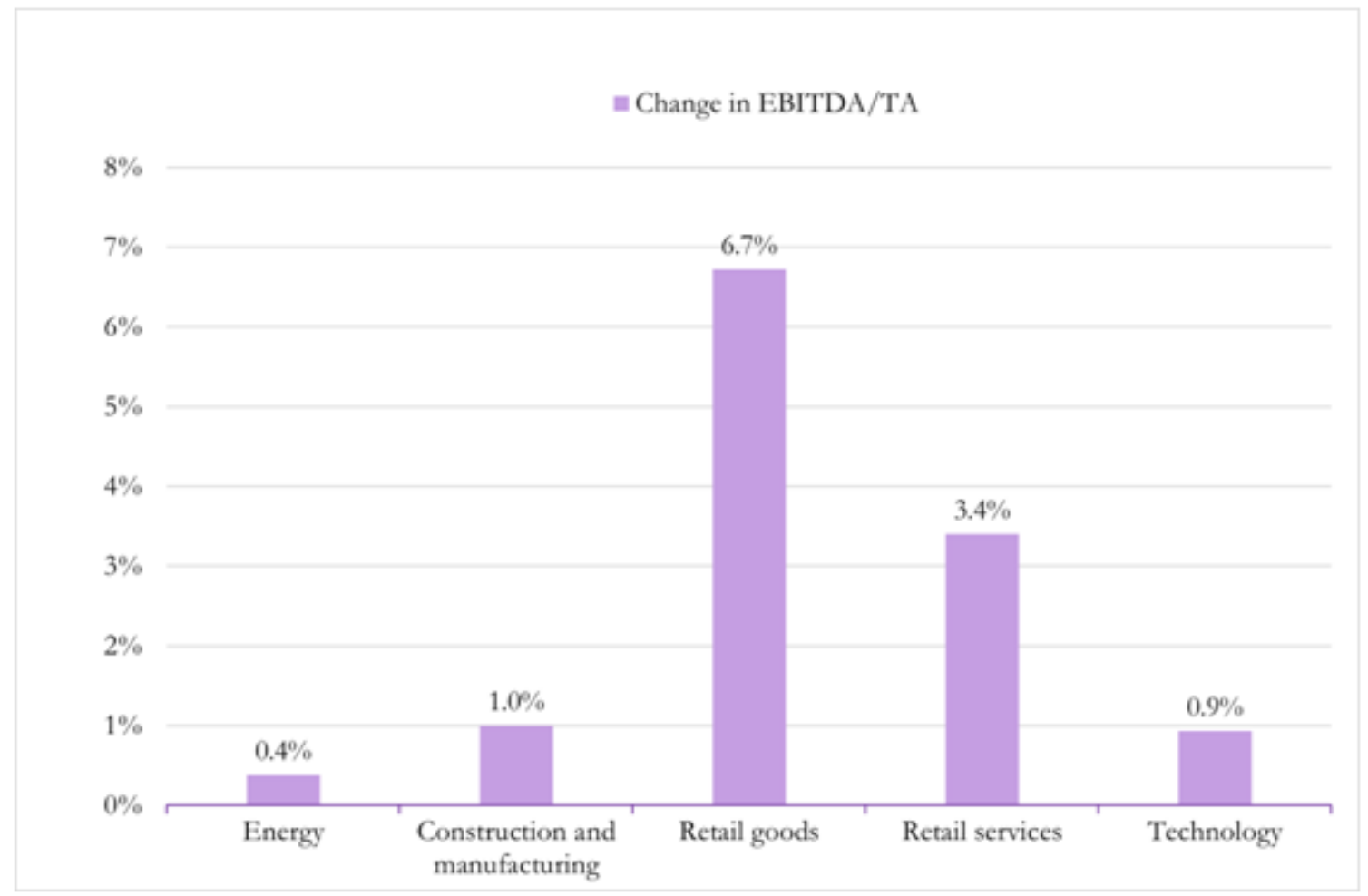

Figure 2. Effect of the capitalization of operating leases by industry

\subsection{Explanatory factors for the change in EBITDA}

Given the importance that investors and analysts attribute to EBITDA, we have investigated the factors that explain the impact of the standard on this accounting measure. The change in EBITDA coincides with operating lease expense, so that the more operating leases the firm has and the higher their amount, the better the business image after the accounting change.

Based on the explanations that the literature has provided on this type of financing, among which is the nature of the assets directly related to the industry in which the firm operates (Smith \& Wakeman, 1985; Krishnan \& Moyer, 1994), we establish an industry hypothesis. Indeed, the greater the specificity of the assets, the lower the preference for leasing, since there are more agency costs (related to the negotiation and control of contracts), which makes the option of full ownership more attractive. On the other hand, when dealing with non-specific assets (typical in short contracts), as is the case in retail industries, leases are more used, since it is easy to dispose of the assets, which remain the property of the lessors. In short, we propose the following hypothesis in an alternative form:

\section{H1: Firms in the retail industries will experience an improvement in EBITDA greater than those of the other industries.}

Next, we refer to the financial situation of the firms. According to the previous research, those who are in a difficult financial situation have more debts and make more frequent use of this type of contract (Smith \& Warner, 1979; Krishnan \& Moyer, 1994; Eisfeldt \& Rampini, 2009; Cornaggia, Franzen \& Simin, 2013). We propose the following hypothesis, also in an alternative way:

\section{H2: Firms with a bigher leverage ratio will experience an improvement in EBITDA greater than those with a lower ratio.}

Finally, we include another hypothesis that captures growth opportunities. As noted by Graham, Lemmon and Schallheim (1998), the operating lease can be used to alleviate the problem of asset substitution, which is more frequent in growing firms. In short, the third hypothesis, also in an alternative form is: 
H3: Firms with more growth opportunities will experience a greater EBITDA improvement than those with fewer opportunities.

The model we use is:

$$
\triangle E B I T D A / T A=a_{0}+a_{1} \text { Industry }+a_{2} L E V+a_{3} M / B+\alpha_{4} \operatorname{Size}+\varepsilon
$$

Where: $\triangle E B I T D A / T A$ is the variation in $E B I T D A$ divided by total assets; Industry is an indicator variable that takes the value 1 if the observation belongs to the industry of retail goods or retail services, and 0 otherwise; $L E V$ is the leverage calculated as total liabilities/total equity; $M / B$ is the market-to-book ratio; Size is measured as the logarithm of net sales. The independent variables are measured without taking into account the impact of the capitalization of operating leases.

For the three explanatory variables (Industry, $L E V$ and $M / B$ ) we expect a positive relationship with the impact on EBITDA. We have introduced the size of the firm into the model (expression 7) since it is a control that is usually incorporated in this type of analysis, but we do not have any concrete expectation regarding its sign.

We use Petersen (2009)'s procedure to estimate clustered robust standard errors that arerobust to heteroscedasticity, serial and cross-sectional correlation with a two dimensional cluster at the firm and year level for the regression model. Additionally, the Pearson correlation coefficients for the variables used in the multivariate analysis were calculated; the results, shown in Table 6, indicate that the correlations between the independent variables are not high. We have also calculated the variance inflation factor of each variable (VIF) and the results do not suggest multicollinearity problems.

\begin{tabular}{|c|c|c|c|c|c|}
\hline Variables & $\triangle E B I T D A / T A$ & Industry & $L E V$ & $\boldsymbol{M} / \boldsymbol{B}$ & Size \\
\hline$\triangle E B I T D A / T A$ & 1 & & & & \\
\hline Industry & $0.568^{* * *}$ & 1 & & & \\
\hline$L E V$ & 0.127 & 0.007 & 1 & & \\
\hline$M / B$ & $0.570^{* * *}$ & $0.407 * * *$ & $0.512^{* * *}$ & 1 & \\
\hline Size & 0.094 & $-0.249 * *$ & 0.008 & -0.143 & 1 \\
\hline
\end{tabular}

Note: $\triangle E B I T D A / T A$ is the variation in EBITDA divided by total assets; Industry is an indicator variable that is 1 if the observation belongs to the retail goods or retail services industry. and 0 otherwise; $L E V$ is leverage calculated as total liabilities/total equity; $M / B$ is the Market-to-book ratio; Size is measured as the logarithm of net sales. $* * *=1 \%$ significance; $* *=5 \% ; *=10 \%$.

Table 6. Pearson correlation coefficients

Table 7 describes the industry classification of the sample following the criteria of the Madrid Stock Exchange. It can be observed that the Construction and manufacturing industry dominates the sample, and the rest are distributed equally, although for the purposes of our analysis, what is relevant is that the retail industries represent 30\%. Table 8 summarizes the descriptive statistics of the variables used in the model, with most of the distributions being skewed to the right.

\begin{tabular}{|l|r|r|}
\hline Industry & Firm-year obs. & Percentage \\
\hline Energy & 12 & $15 \%$ \\
\hline Construction and manufacturing & 32 & $40 \%$ \\
\hline Retail goods & 12 & $15 \%$ \\
\hline Retail services & 12 & $15 \%$ \\
\hline Technology & 12 & $15 \%$ \\
\hline Total & 80 & $100 \%$ \\
\hline
\end{tabular}

Note: Classification according to the Madrid Stock Exchange.

Table 7. Industry classification 
16, the issue that constitutes the main objective of this work. The constructive capitalization method has been used to estimate the assets and liabilities that according to the standard in force are not recognized on the balance sheet. The results reveal that the total amount of unaccounted liabilities is around 20 billion euros, which will mean an increase of $4.81 \%$ with respect to the liabilities recognized on the balance sheet. Notwithstanding the foregoing, we must clarify that the results obtained in this and other works are influenced by the methodology for calculating the off-balance-sheet items. Through the sensitivity analysis performed, we verify that using one interest rate or another does not significantly affect the descriptive statistics, nor does it modify the assumption about the remaining useful lease life, although using the factor method or not discounting the liability does lead to significantly different figures. In particular, the factor method means that the average increase in liabilities is almost 4 times higher than with the constructive method. These results can be understood as a "relief" for certain non-sophisticated users who, when applying simple procedures, may come to believe that the real debts are much greater than those that will eventually emerge.

Next, we verify whether the change in a series of financial metrics and ratios, some of which are frequently included as restrictions in debt contracts (covenants), is statistically significant. The results suggest that IFRS 16 significantly affects the financial metrics, and in particular the non-current asset turnover and the debt quality, followed by leverage and ROA. We must stress that not all ratios are penalised, since the financial profitability ratio (ROE) and the market-to-book ratio improve. On the other hand, we show that there are notable industry differences. It is not surprising that the firms in the retail goods and retail services industries are the most affected by the accounting change, given that these types of contracts are widely used in these industries.

Despite the fact that, like other works, our results show that the ratios are significantly affected by capitalization, this does not necessarily mean that there will be noncompliance in the covenants when applying IFRS 16 . There are various reasons that may account for this: i) Current restrictions may take into account off-balance-sheet information and ratios are adjusted with this information (for example, as has been done in this work or through some other alternative procedure), ii) the established restrictions "freeze the accounting practices" that serve as a basis for calculating them, and iii) the three-year implementation period established by the IASB is sufficient to understand the effects of the change and consequently alter the established limits. In spite of everything, if the inclusion on the balance sheet provides unknown information that reveals a greater risk, it is reasonable to assume that renegotiations will take place in the clauses.

As indicated above, certain metrics improve when applying the new standards, and in particular EBITDA, which excludes depreciation and interest from its computation. In the study we found that the larger firms, which have a higher valuation in the capital market and belong to the retail industries, see this metric improved the most.

We conclude this work by referring to its implications and limitations, as well as possible lines of research in the future. We understand that learning about the accounting change should help to understand the "worsening" and the "improvement" in the financial metrics. The firm does not change when applying the new standard, but it does provide greater transparency that should help to make better decisions, if previously the risks were ignored or were not properly assessed. We also believe that the work can be employed to initiate debt renegotiations, if the risks were initially overlooked or if mechanical rules were incorporated that may be breached. Regarding the limitations of this study, there is no doubt that the number of firms is small, which implies that certain precautions should be taken in the generalisation of the results. Although the method used for capitalization requires the introduction of some hypotheses for its implementation, through the sensitivity tests we believe that the robustness of our conclusions has increased. We must point out that we have not attempted in this work to detect all the possible impacts of the new way of accounting for operating leases, and in particular the valuation aspects and the determination of implementation costs, which in some cases could be elevated. Finally, we refer to the lines of research that could arise after the adoption of IFRS 16. From our point of view, the ex post analysis of the possible change in the behaviour of firms with respect to operating leases, as well as the decisions of the users, constitute new research opportunities of great interest. 


\section{Acknowledgements}

The authors gratefully acknowledge the assistance of Raquel Cancho in gathering data and the valuable comments of two reviewers.

\section{Declaration of Conflicting Interests}

The authors declared no potential conflicts of interest with respect to the research, authorship, and/or publication of this article.

\section{Funding}

The authors received no financial support for the research, authorship, and/or publication of this article.

\section{References}

Abdel-Khalik, A.R. (1981). The Economic Effects on Lessees of FASB Statement No. 13, Accounting for Leases. Stamford, CT.: FASB

Barral, A., Cordobés, M., \& Ramírez, J. (2014). Los arrendamientos operativos: impacto de su reconocimiento en los estados financieros y en la política de financiación de las compañías españolas y del Reino Unido. Revista de Contabilidad, 17(2), 212-223. https://doi.org/10.1016/j.rcsar.2014.08.001

Beattie, V., Edwards, K., \& Goodacre, A. (1998). The impact of constructive operating lease capitalisation on key accounting ratios. Accounting and Business Research, 28(4), 233-254.

https://doi.org/10.1080/00014788.1998.9728913

Beattie, V., Goodacre, A., \& Thomson, S. (2000). Recognition versus Disclosure: An Investigation of the Impact on Equity Risk using UK Operating Lease Disclosures. Journal of Business Finance \& Accounting, 27(9-10), 1185-1224. https://doi.org/10.1111/1468-5957.00352

Beatty, A., Liao, S., \& Weber, J. (2010). Financial reporting quality, private information, monitoring, and the leaseversus-buy decision. The Accounting Review, 85(4), 1215-1238. https://doi.org/10.2308/accr.2010.85.4.1215

Beneish, M., \& Press, E. (1993). Cost of Technical Violation of Accounting-Based Debt Covenants. The Accounting Review, 68, 233-257.

Bennett, B.K., \& Bradbury, M.E. (2003). Capitalizing non-cancelable operating leases. Journal of International Financial Management \& Accounting, 14(2), 101-114. https://doi.org/10.1111/1467-646X.00091

Bryan, S.H, Lilien, S., \& Martin, D.R. (2010). The Financial statement effects of capitalizing operating leases. Assessing the impact of the right-to-use model. The CPA Journal, August, 36-41.

Cooper, S. (2017). Implementation Update: IFRS 16 Leases. January 2017.

Cornaggia, K.J., Franzen, L.A., \& Simin, T.T. (2013). Bringing assets onto the balance sheet. Journal of Corporate Finance, 22(September), 345-360. https://doi.org/10.1016/j.jcorpfin.2013.06.007

Dechow, P.M., Ge, W., Larson, C.R., \& Sloan, R.G. (2011). Predicting material accounting misstatements. Contemporary Accounting Research, 28(1), 17-82. https://doi.org/10.1111/j.1911-3846.2010.01041.x

Deloitte (2011). How prepared is your organization to cope with these new standards? A Deloitte survey on the FASB's proposed changes to lease accounting standards. Retrieved from: http://www.iasplus.com/en/binary/usa/1102usleasessurvey.pdf (Last access date: December $3^{\text {rd }}$, 2015).

Demerjian, P.R. (2011). Accounting standards and debt covenants: Has the "balance sheet approach" led to a decline in the use of balance sheet covenants?. Journal of Accounting \& Economics, 52, 278-202. https://doi.org/10.1016/j.jacceco.2011.08.004

Duke, J.C., Hsieh, S.-J., \& Su, Y. (2009). Operating and synthetic leases: Exploiting financial benefits in the postEnron era. Advances in Accounting, 25(1), 28-39. https://doi.org/10.1016/j.adiac.2009.03.001 
Durocher, S. (2008). Canadian evidence on the constructive capitalization of operating leases. Accounting Perspectives,7(3), 227-256. https://doi.org/10.1506/ap.7.3.2

EFRAG (2016). IFRS 16 Leases. Quantitative assessment of accounting impacts. July. Paper 08-02.

Eisfeldt, A., \& Rampini, A. (2009). Leasing, ability to repossess, and debt capacity. Review of Financial Studies, 22(4), 1621-1657. https://doi.org/10.1093/rfs/hhn026

Ely, K. (1995). Operating lease accounting and the market's assessment of equity risk. Journal of Accounting Research, 33, 397-415. https://doi.org/10.2307/2491495

FASB (Financial Accounting Standards Board) (1976). Accounting for Leases. Statement of Financial Accounting Standards No. 13. Stamford, CT: FASB.

Fitó, M.Á., Moya, S., \& Orgaz, N. (2013). Considering the effects of operating lease capitalization on key financial ratios. Revista Española de Financiación y Contabilidad, 42(159), 341-369. https://doi.org/10.1080/02102412.2013.10779750

Franz, D.R., HassabElnaby, H.R., \& Lobo, G.F. (2014). Impact of proximity to debt covenant violation on earnings management. Review of Accounting Studies, 19, 473-505. https://doi.org/10.1007/s11142-013-9252-9

Fülbier, R.U., Silva, J.L., \& Pferdehirt, M.H. (2008). Impact of lease capitalization on financial ratios of listed German companies. Schmalenbach Business Review, 60(2), 122-144. https://doi.org/10.1007/BF03396762

Gill de Albornoz, B., Rusanescu, S., \& Cabedo, P. (2017). Las nuevas normas contables de arrendamientos: Causas y potenciales efectos económicos. Revista de Contabilidad y Tributación, 406, 207-246.

Giner, B., \& Pardo, F. (2017). Operating lease decision and the impact of capitalization in a bank-oriented country. Applied Economics, 49(19), 1886-1900.

Goodacre, A. (2003). Operating lease finance in the UK retail sector. International Review of Retail, Distribution and Consumer Research, 13(1), 99-125. https://doi.org/10.1080/0959396032000065373

Graham, J.R., Lemmon, M.L., \& Schallheim, J.S. (1998). Debt, leases, taxes and the endogeneity of corporate tax status. Journal of Finance, 53, 131-162. https://doi.org/10.1111/0022-1082.55404

Imhoff, E.A., Lipe, R.C., \& Wright, D.W. (1991). Operating leases: impact of constructive capitalization. Accounting Horizons, 5(1), 51-63.

Imhoff, E.A., Lipe, R.C., \& Wright, D.W. (1993). The effects of recognition versus disclosure on shareholder risk and executive compensation. Journal of Accounting, Auditing and Finance, 8(4), 335-368.

https://doi.org/10.1177/0148558X9300800402

Imhoff, E.A., Lipe, R.C., \& Wright, D.W. (1997). Operating leases: Income effects of constructive capitalization. Accounting Horizons, 11(2), 12-32.

Imhoff, E.A., \& Thomas, J. (1988). Economic consequences of accounting standards: The lease disclosure rule change. Journal of Accounting and Economics, 10, 277-310. https://doi.org/10.1016/0165-4101(88)90006-7

IASC (International Accounting Standards Committe) (1997). Norma Internacional de Contabilidad. NIC 17 Arrendamientos.

IASB (International Accounting Standards Board) (2009). Preliminary Views. Leases. DP/2009/01. IFRS Foundation. March. London.

IASB (International Accounting Standards Board) (2010). Exposure Draft. Leases. ED/2010/9. IFRS Foundation. August. London.

IASB (International Accounting Standards Board) (2013). Exposure Draft. Leases. ED/2013/6. IFRS Foundation. May. London.

IASB (International Accounting Standards Board) (2016a). Leases. International Financial Reporting Standard No. 16. IFRS Foundation. March. London. 
IASB (International Accounting Standards Board) (2016b). Effects Analysis. IFRS 16 Leases. IFRS Foundation. January. London.

Krishnan, V.S., \& Moyer, R.C. (1994). Bankruptcy costs and the financial leasing decision. Financial Management, 23, 31-42. https://doi.org/10.2307/3665737

Molina, H., \& Mora, A. (2015). Cambios conceptuales en la contabilidad de los arrendamientos: Retos normativos y académicos. Revista de Contabilidad, 18(1), 99-113. https://doi.org/10.1016/j.rcsar.2015.01.001

Mulford, C., \& Gram, M. (2007). The effects of lease capitalization on various financial measures: An analysis of the retail industry. Journal of Applied Research in Accounting \& Finance, 2(2), 3-13.

Nelson, A.J. (1963). Capitalising leases: The effect on financial ratios. Journal of Accountancy, 41, 49-58.

Nikolaev, V.N. (2010). Debt Covenants and Accounting Conservatism. Journal of Accounting Research, 48(1), 137-175. https://doi.org/10.1111/j.1475-679X.2009.00359.x

Ortiz, E., \& Marín, S. (2014). Global Reporting Initiative (GRI) as recognized guidelines for sustainability reporting by Spanish companies on the IBEX 35: Homogeneity in their framework and added value in the relationship with financial entities. Intangible Capital, 10(5), 855-872. https://doi.org/10.3926/ic.492

Paik, D.G.H., van der Laan Smith, J.A., Lee, B.B., \& Yoon, S.W. (2015). The relation between accounting information in debt covenants and operating leases. Accounting Horizons, 29(4), 969-996. https://doi.org/10.2308/acch-51214

Petersen, M.A. (2009). Estimating standard errors in finance panel data sets: comparing approaches. Review of Financial Studies, 22(1), 435-480. https://doi.org/10.1093/rfs/hhn053

PwC (2016). A study on the impact of lease capitalization: IFRS 16: The new leases standard. February.

Reverte, C. (2009). Determinants of Corporate Social Responsibility Disclosure Ratings by Spanish Listed Firms. Journal of Business Ethics, 88, 351-366. https://doi.org/10.1007/s10551-008-9968-9

Reverte, C. (2016). Corporate social responsibility disclosure and market valuation: Evidence from Spanish listed firms. Review of Managerial Science, 10(2), 411-435. https://doi.org/10.1007/s11846-014-0151-7

Scott, D. (2017). Implementation Update: IFRS 16 Leases. January 2017.

Smith, C.W., \& Warner, J.B. (1979). Bankruptcy, Secured Debt, and Optimal Capital Structure: Comment. Journal of Finance, 34, 247-251. https://doi.org/10.1111/j.1540-6261.1979.tb02085.x

Smith, C.W., \& Wakeman, L.M. (1985). Determinants of corporate leasing policy. Journal of Finance, 40, 895-908. https://doi.org/10.1111/j.1540-6261.1985.tb05016.x 


\section{Versión en español}

Título: La capitalización de los arrendamientos operativos: Análisis del impacto en las empresas del IBEX 35

\section{Resumen}

Objeto: Este trabajo investiga las implicaciones del cambio en la normativa contable referido a los arrendamientos operativos sobre las empresas y los usuarios de la información financiera.

Diseño/metodología/enfoque: Se utiliza el método de capitalización constructivo para estimar los pasivos y activos por arrendamiento, y se analiza ex ante el impacto normativo sobre las empresas no financieras del IBEX 35. Mediante tests no paramétricos se examina el efecto sobre ciertas ratios, y mediante un modelo de regresión multivariante se investigan las características empresariales que explican la variación del EBITDA.

Aportaciones y resultados: Las ratios resultan significativamente afectadas por la capitalización de los arrendamientos operativos. El análisis explicativo evidencia que las empresas de mayor tamaño, con mayor valoración en el mercado y que pertenecen a los sectores de consumo presentan un mayor incremento en el EBITDA.

Limitaciones: El tamaño muestral es reducido, lo que impone cierta cautela en la generalización de los resultados. Se han introducido ciertas hipótesis para aplicar el método constructivo, si bien mediante los tests de sensibilidad se ha verificado que los resultados son consistentes.

Implicaciones prácticas: En ciertos casos, convendría iniciar renegociaciones en los contratos, en particular en los de deuda, para evitar incumplimientos. El método constructivo conlleva deudas y activos sensiblemente menores que otros métodos más simples (como el del factor), por lo que estos resultados pueden ser un alivio para ciertos usuarios no sofisticados.

Implicaciones sociales: Los inversores, accionistas y prestamistas, y otros usuarios tendrán información más transparente, lo que debería repercutir en una mejor toma de decisiones.

Originalidad / Valor Añadido: Se complementa el estudio del impacto sobre las magnitudes del balance y las ratios financieras con un análisis descriptivo, que tiene en cuenta el sector, y con la modelización de los factores explicativos del cambio en el EBITDA.

Palabras Clave: Arrendamientos operativos, NIIF 16, Capitalización constructiva, Ratios financieras, Impacto normativo

Códigos JEL: G32, M41, M48

\section{Introducción}

La normativa sobre la contabilización de los arrendamientos ha experimentado cambios importantes a lo largo de los años, y el más reciente se ha llevado a cabo en 2016 con la aprobación de la Norma Internacional de Información Financiera (NIIF) 16 (IASB, 2016a) y el Accounting Standards Update (ASU) No. 2016-02 (Topic 842) por parte del International Accounting Standards Board (IASB) y el Financial Accounting Standards Board (FASB), respectivamente. Dichas normas, aunque no idénticas, coinciden en lo fundamental, todos los contratos de arrendamiento deben figurar como activos y pasivos en el balance. Se trata de un cambio que, a juzgar por las reticencias que principalmente las empresas afectadas han mostrado antes de su aprobación, podría tener un 
impacto económico considerable. Dado que según el Reglamento (CE) 1606/2002 del Parlamento Europeo y del Consejo relativo a la aplicación de las normas internacionales de contabilidad, una vez aceptadas dichas normas por la Comisión Europea (CE) son de obligado cumplimiento para las cuentas consolidadas de las empresas cotizadas en la Unión Europea (UE), en este trabajo vamos a centrarnos en la NIIF 16: "Arrendamientos". Esta norma ha sido adoptada en el último trimestre de 2017 y entrará en vigor en 2019. Por otra parte, en España es práctica habitual aproximar la normativa local —Plan General de Contabilidad (PGC) y resoluciones del Instituto de Contabilidad y Auditoría de Cuentas (ICAC) - a lo dispuesto en las NIIF, lo que sugiere que la nueva norma podría tener un efecto cascada y provocar cambios que afecten a otras empresas y estados financieros. En este sentido, Molina y Mora (2015, p. 111) señalan: "Existe además la creencia de que un cambio de modelo tan radical puede acabar trasladándose a las regulaciones nacionales y a las entidades de menor tamaño que no cotizan en los mercados de valores".

En este trabajo examinamos el impacto de la norma sobre los estados financieros de una muestra de empresas españolas, con el objetivo de conocer cómo pueden alterarse ciertas magnitudes clave para enjuiciar su situación financiera. Asimismo, analizamos las características de las empresas que pueden resultar más afectadas por el cambio normativo.

La gran oposición a esta norma se puede evidenciar a través de su compleja gestación. El proceso de elaboración de normas (due process) del IASB conlleva una serie de etapas, que incluyen necesariamente la publicación de al menos un borrador de norma. En este caso, además, se emitió antes un documento de trabajo (Discussion Paper DP) (IASB, 2009) y fueron dos los borradores emitidos (Exposure Draft - ED) (IASB, 2010 y 2013). Por otra parte, dichos documentos deben ser sometidos a la opinión pública para que los interesados puedan hacer sugerencias y comentarios; considerando los diversos documentos referidos a este proyecto se enviaron más de 1.700 cartas, lo que excede a las normalmente enviadas en otros casos. También requiere el proceso normativo la realización de un análisis de los efectos esperados de la norma. En 2016 se publicó el análisis sobre este proyecto, entre cuyos resultados destacan los casi 3 billones de dólares de compromisos de pago por arrendamiento que, siguiendo lo establecido en las normas en vigor, no se incluyen en el balance, pero son divulgados en las memorias de las empresas que cotizan y emplean las NIIF o los USGAAP (IASB, 2016b). En qué medida su reconocimiento en el balance puede tener consecuencias económicas y afectar a los contratos de deuda y remuneración, entre otros, así como mejorar las decisiones de los inversores, es la cuestión que subyace a este trabajo.

Basándonos en la información manualmente recogida que las empresas del IBEX 35 proporcionan en la memoria sobre los compromisos de pago por arrendamientos operativos, llevamos a cabo un análisis ex ante de la aplicación de la NIIF 16. Para ello, habida cuenta de la información divulgada e introduciendo ciertas hipótesis, simulamos el impacto de la nueva norma capitalizando los arrendamientos operativos mediante el método constructivo. Contrastamos si el cambio en una serie de magnitudes y ratios financieras, algunas frecuentemente incluidas como restricciones en los contratos de deuda (covenants), es estadísticamente significativo. Los resultados sugieren que la nueva normativa conllevará cambios significativos en las magnitudes financieras, aunque hay diferencias entre las empresas de distintos sectores; si bien parece que el impacto será menor que el sugerido en algunos trabajos internacionales realizados recientemente (EFRAG, 2016; IASB, 2016b; PwC, 2016). Ello puede tener efectos importantes en algunos contratos siempre y cuando: i) no se tuvieron ya en cuenta a la hora de pactar los covenants, y ii) no se revisen a la luz de la nueva norma. Sin embargo, dada la fijación que existe al utilizar ciertas ratios derivadas de las magnitudes financieras, es posible que las restricciones se incumplan en ciertos casos, lo que, sin duda, conllevaría efectos económicos no despreciables. Por otra parte, mediante un análisis multivariante examinamos los aspectos que explican el impacto de la norma, y nos centramos en su impacto en una magnitud frecuentemente empleada por los analistas financieros, el EBITDA (earnings before interest, taxes, depreciation and amortization), que, a diferencia de las antes indicadas, mejora al aplicar la nueva regulación. Los resultados revelan que las empresas más grandes, que tienen una mayor valoración en el mercado y pertenecen a los sectores de consumo mejoran más esa magnitud. Estos resultados contribuyen a aumentar el conocimiento sobre cómo el cambio contable va a afectar a las empresas españolas, y a evitar malos entendidos sobre sus implicaciones. En efecto, como consecuencia de la norma contable las empresas no "empeoran" o 
"mejoran" su situación económico-financiera, sino que la información proporciona una imagen más transparente de la misma, lo que debe redundar en una mejor toma de decisiones de inversión y financiación. Asimismo, se advierte de los inconvenientes de emplear métodos heurísticos, dado que si bien son más simples, pueden conllevar un mayor error.

Al objeto de tener una mejor idea del cambio normativo, conviene en primer lugar valorar las dificultades del proceso de aprobación de la NIIF 16, para después hacer una presentación de las principales novedades en el tratamiento contable de los arrendamientos. Seguidamente, se exponen las conclusiones de los estudios que han analizado el impacto del cambio. Continúa el trabajo con una parte empírica en la que se aborda el análisis del cambio normativo en las empresas del IBEX 35 y, por último, en la sección final se exponen las conclusiones.

\section{E1 desarrollo del proyecto de arrendamientos}

No sólo el PGC sino la noma contable internacional y la norteamericana en vigor —NIC 17 (IASC, 1997) y Statement of Financial Accounting Standard (SFAS) 13 (FASB, 1976), redenominada Accounting for leases, ASC Topic 840, respectivamente - distinguen entre arrendamiento financiero y operativo, y, basándose en la transferencia de los riesgos y beneficios inherentes a la propiedad del activo, establecen dos procedimientos diferenciados. Si estos se transfieren, el arrendamiento se califica como financiero, dando lugar al reconocimiento de un activo y un pasivo en el balance. De lo contrario, el arrendamiento se considera operativo y no da lugar a reconocimiento en el balance, sino que se refleja como un gasto en la cuenta de pérdidas y ganancias cuando se devenga, y debe proporcionarse información en la memoria sobre los compromisos de pago.

En la medida que los arrendamientos operativos no penalizan las ratios de endeudamiento y conllevan normalmente una mejor rentabilidad, las empresas prefieren clasificar los arrendamientos como operativos. Esto ha llevado a que por ejemplo las agencias de rating, como Standard \& Poor's y Moody's hayan desarrollado modelos para capitalizar los arrendamientos fuera del balance. La cuestión es si aciertan en los ajustes, y si otros usuarios son conscientes de las deudas no reconocidas. En este sentido, Mr. Cooper, miembro del IASB en aquellas fechas, alertaba sobre la magnitud de las cifras finalmente reconocidas, esto es, sobre la deuda que finalmente aflore, ya que no es obvio que se imponga la misma exigencia o el mismo juicio crítico a las cifras divulgadas que a las incluidas en los estados principales, concretamente se refiere al reconocimiento de ampliaciones en el contrato y opciones de cancelación. Como consecuencia es posible que se reconozcan cifras distintas a las que sugieren los arrendamientos divulgados (Cooper, 2017).

Así pues, para evitar los contratos ad hoc y la confusión sobre la magnitud de las deudas existentes, tanto el IASB como el FASB se plantearon desarrollar un proyecto que eliminara la diferenciación. Dicho proyecto iniciado en 2006, se abordó en el marco del proyecto de convergencia entre ambas instituciones, abandonado en 2013, por lo que no es de extrañar que haya dado lugar a dos normas no idénticas, aunque similares, que imponen la capitalización de todos los arrendamientos.

El IASB fiel al DP (IASB, 2009) y al ED/2010/9 (IASB, 2010) entiende que todos los contratos deben capitalizarse y dar lugar al reconocimiento de gasto por intereses (decreciente) y gasto por amortización del activo (constante normalmente). Sin embargo, el FASB en la línea del ED/2013/6 (IASB, 2013) diferencia entre dos categorías de arrendamientos, a los que llama financieros y operativos en función del consumo de los beneficios del activo que el arrendatario espera hacer. Si el arrendatario espera consumir una parte importante de los mismos, el arrendamiento es financiero, de lo contrario, es operativo. Sólo en los primeros se distingue en la cuenta de pérdidas y ganancias la amortización del activo de la carga financiera, siendo la suma de ambos decreciente, mientras que en los arrendamientos operativos el gasto es constante. No obstante, en ambos casos se reconoce el activo por derecho de uso y el pasivo en el balance.

\section{E1 nuevo modelo normativo según la NIIF 16}

Es importante destacar que, a diferencia de lo actualmente establecido en la NIC 17, la NIIF 16 exige para la identificación de un contrato de arrendamiento, además del derecho de uso de un activo, el control sobre ese derecho de uso. El arrendatario debe reconocer un activo, el derecho de uso, que representa su derecho a utilizar 
el activo arrendado subyacente, y un pasivo por arrendamiento, que representa su obligación de hacer frente a los pagos derivados del mismo. No obstante, la nueva norma permite al arrendatario la no aplicación de este criterio general en dos casos: los arrendamientos a corto plazo y los de bienes de escaso valor. Un contrato de arrendamiento se considera a corto plazo si, en la fecha de inicio, la duración es de hasta 12 meses, y si el contrato no contiene una opción de compra. Con respecto a los arrendamientos de bienes de escaso valor (por ejemplo: tablets, ordenadores, pequeños artículos de mobiliario de oficina y teléfonos), se debe considerar el valor del activo subyacente en función de su valor cuando es nuevo, independientemente de la edad del activo arrendado. Ninguna de estas dos excepciones está contemplada en la vigente NIC 17.

Si un mismo contrato incluye además de un arrendamiento otros componentes (por ejemplo, servicios de mantenimiento $\mathrm{u}$ otros servicios), en principio, se deben separar y contabilizar de forma independiente (siguiendo la norma correspondiente en función de su naturaleza). No obstante, la NIIF 16 permite no separar los componentes, por clase de activo subyacente, $\mathrm{y}$, en su lugar, contabilizarlo todo como un arrendamiento único (párrafo 15, IASB, 2016a).

En general, el tratamiento contable de los arrendamientos en la NIIF 16 es similar al que establecen las normas actuales para los arrendamientos financieros, salvo por algunas diferencias. Así, el pasivo por arrendamiento incluye el valor actual de las cuotas futuras del arrendamiento, que básicamente son: cuotas fijas, incluyendo las denominadas cuotas fijas "en sustancia" (menos cualquier incentivo que vaya recibir del arrendador); cuotas variables referenciadas a un índice o a un tipo de interés (por ejemplo, al IPC o al Euribor); importes que se esperan pagar por valores residuales garantizados; precio de ejercicio de la opción de compra (si el arrendatario tiene certeza razonable de que se ejercerá); pagos de penalizaciones por terminar el arrendamiento (si la duración del arrendamiento sugiere que el arrendatario ejercerá la opción para terminarlo). Sin embargo, en la NIC 17 las cuotas de carácter contingente no se incluyen en el valor inicial del pasivo, lo que puede suponer una diferencia relevante, ya que estos pagos en la actualidad se reconocen en el resultado de explotación, independientemente de la clasificación del arrendamiento.

En cuanto al tipo de interés implícito del arrendamiento, dadas las dificultades para recabar la información para su determinación, como señala Mr. Scott, miembro del IASB, es probable que muchas empresas empleen la alternativa de la tasa de interés incremental (Scott, 2017).

Por su parte, el activo se valora inicialmente por el importe inicial del pasivo más cualquier pago realizado con anterioridad al inicio del contrato (menos incentivos, si los hubiera), los costes directos incurridos por el arrendatario y los costes de rehabilitación, desmantelamiento y retiro del activo estimados. Posteriormente, el activo se debe amortizar usando un método sistemático y racional (generalmente lineal), y adicionalmente habría que reconocer, si procede, su posible deterioro de valor. Dado que al pasivo se le aplica el método del tipo de interés efectivo, el reconocimiento de gastos por arrendamiento no es lineal (como ocurre generalmente en los arrendamientos operativos en la actualidad), sino decreciente.

Además, el arrendatario debe revisar el pasivo por arrendamiento en algunos casos como: i) cambios en el importe a pagar por una garantía del valor residual, ii) cambios en las cuotas de arrendamiento por variaciones en un índice o en un tipo de interés utilizado para determinar dichas cuotas, iii) cambios en la duración del arrendamiento inicialmente establecido como consecuencia de una modificación en el periodo no cancelable del mismo, y iv) cambios en la evaluación de ejercicio de una opción de compra (IASB, 2016a, párr. 40-43). Los dos primeros cambios se deben calcular utilizando el tipo de interés original, mientras que para los dos últimos casos, los nuevos flujos de efectivo se deben descontar utilizando un nuevo tipo de interés, revisado en la fecha de cambio. El importe de la modificación del pasivo se debe reconocer como un ajuste en el valor del activo, salvo que su valor sea cero, en cuyo caso se debe imputar cualquier cantidad restante a la cuenta de pérdidas y ganancias.

Con respecto a la presentación en los estados financieros, el activo y el pasivo por arrendamiento deben figurar en el balance identificados de forma separada de otros activos y pasivos, pero también puede no hacerse e informar en la memoria de esta peculiaridad. En la cuenta de ganancias y pérdidas, al igual que sucede en la NIC 17 para los arrendamientos financieros, el arrendatario debe presentar el gasto por intereses derivado del pasivo 
por arrendamiento separadamente de la amortización del activo de derecho de uso. Así, el gasto por intereses es un gasto financiero, mientras que la amortización es de explotación. En el estado de flujos de efectivo, los pagos en efectivo en concepto de principal del pasivo por arrendamiento se deben clasificar como una actividad de financiación, mientras que los pagos en efectivo por los intereses del pasivo por arrendamiento se deben presentar en coherencia con otros pagos de intereses. Sin embargo, las cuotas de arrendamientos a corto plazo, pagos por arrendamientos de activos de escaso valor y cuotas por arrendamiento variables no incluidas en la valoración del pasivo por arrendamiento se deben incluir en las actividades de explotación en la cuenta de pérdidas y ganancias, y se consideran actividades operativas en el estado de flujos de efectivo.

\section{Efectos de la capitalización de los arrendamientos en la literatura previa}

Al trabajo pionero de Nelson (1963), previo a que alguna norma impusiera la capitalización de los arrendamientos, le sucedieron los que analizaron el impacto de la norma americana que obligó a capitalizar los arrendamientos financieros (Imhoff \& Thomas, 1988), pero más adelante otros trabajos, también referidos a EE.UU., se centraron en la capitalización de los operativos (Imhoff, Lipe \& Wright, 1993; Mulford \& Gram, 2007). Este enfoque ha sido también abordado en otros países, tales como Reino Unido, por Beattie, Edwards y Goodacre (1998) y Goodacre (2003), Nueva Zelanda por Bennett y Bradbury (2003), Canadá por Durocher (2008), Alemania por Fülbier, Silva y Pferdehirt (2008), España por Fitó, Moya y Orgaz (2013), Barral, Cordobés y Ramírez (2014) — que también consideran Reino Unido—, Giner y Pardo (2017) y Gill de Albornoz, Rusanescu y Cabedo (2017). Para ello se estima el importe de las deudas no contabilizadas, que se incorporan en los estados financieros como si estuvieran reconocidas por las empresas. La conclusión general es que las ratios (y sobre todo las de balance y, muy especialmente, las de endeudamiento) resultan afectadas, así como algunas de rentabilidad, si bien detectan diferencian importantes entre empresas y entre sectores. Es precisamente el empeoramiento en los indicadores financieros lo que ayuda a entender la fuerte reticencia de las empresas a la capitalización de los arrendamientos en general, y de los operativos en particular, tal y como se ha puesto de manifiesto en las cartas de comentarios enviadas a lo largo del proceso normativo.

El estudio de PwC sobre el impacto de la capitalización de los arrendamientos operativos, referido a 3,199 empresas cotizadas que usan las NIIF, revela un aumento de la deuda en mediana del $21 \%$ y en el EBITDA del $11 \%$ en la UE. Respecto a la ratio de endeudamiento (deuda total dividido por EBITDA) pasa de 1.55 a 1.78, mientras que la solvencia disminuye del $46 \%$ al $41.6 \%$. Es importante señalar que el impacto difiere entre sectores, siendo especialmente destacable en los sectores minorista, líneas aéreas, servicios profesionales y salud (PwC, 2016). EFRAG publicó en 2016 un estudio sobre el impacto en la UE basándose en las mayores empresas por capitalización de mercado y con mayor volumen de arrendamientos operativos (EFRAG, 2016). Esencialmente concluye que el cambio supone un aumento promedio en el nivel de deuda respecto de la deuda financiera del $4 \%$ (siendo el sector más afectado el energético, un 26\%), aunque si se excluye el sector financiero el aumento alcanza el 16\%, mientras que el neto patrimonial se reduce en un $0.6 \%$ (excluyendo el sector financiero en un $0.9 \%$ ). También en 2016 se hizo público el análisis de efectos del IASB; basándose en 1,022 empresas que aplican las NIIF, de las que 348 son europeas, se concluye que el aumento en la cuantía de deudas es de 1.66 billones de dólares, lo que representa un 5.4\% del total del activo, que alcanza el $20 \%$ en los sectores aéreo, minorista, transporte y ocio (IASB, 2016b). Conviene destacar que, a excepción del estudio de EFRAG, los otros análisis excluyen el sector financiero.

Por otra parte, a través de una encuesta de opinión a 284 ejecutivos sobre cómo la nueva forma de contabilizar los arrendamientos operativos puede afectar a las empresas, Deloitte (2011) concluye que la norma puede tener un efecto importante y las empresas no parecen estar preparadas. El 68\% de los encuestados considera que aumentarán las ratios de endeudamiento (en concreto deuda sobre neto patrimonial), lo que según el $40 \%$ de los encuestados dificultará obtener financiación, reducirá la duración de los arrendamientos y un $25 \%$ considera que hará que los arrendatarios prefieran la compra al alquiler. Otras ratios sobre las que se les preguntó son ROA (return on assets) y la cobertura de intereses, y según el $49 \%$ y el $40 \%$, respectivamente, el efecto también será relevante. También son cuestionados sobre el impacto en los márgenes operativos y en el EBITDA, respondiendo el $37 \%$ y el $41 \%$, respectivamente, que el impacto será material. 
Como se ha indicado anteriormente, la diferente forma de contabilizar los arrendamientos financieros y operativos tiene claras implicaciones sobre la aparente situación financiera de la empresa, que probablemente haya fomentado que las empresas hayan diseñado contratos ad hoc para evitar el reconocimiento de los arrendamientos (Imhoff \& Thomas, 1988; Duke, Hsieh \& Su, 2009; Beatty, Liao \& Weber, 2010; Bryan, Lilien \& Martin, 2010; Dechow, Ge, Larson \& Sloan, 2011). Abdel-Khalik (1981) es uno de los primeros autores en señalar que las empresas optan por arrendamientos de tipo operativo para evitar incumplir las restricciones establecidas en los contratos de endeudamiento. En efecto, ciertas ratios financieras se incluyen con frecuencia en los contratos de deuda como restricciones o covenants (Beneish \& Press, 1993; Nikolaev, 2010; Franz, HassabElnaby \& Lobo, 2014).

Como se ha puesto de manifiesto, la aplicación de la NIIF 16 alterará en menor o mayor medida las magnitudes contables y las ratios financieras, ahora bien, si esto va a provocar algún incumplimiento en los covenants, que exija renegociar las condiciones de los préstamos, entre otros acuerdos contractuales, es un aspecto que no se puede predecir sin tener un conocimiento preciso de los términos de los contratos y sus restricciones. Resultan de interés ciertos resultados de la encuesta antes referida que revelan que el $44 \%$ de los ejecutivos entrevistados considera que sí tendrá un impacto en dichas restricciones, si bien el 32\% considera que no lo ten drá (Deloitte, 2011). Frente a estas opiniones divididas hay que contraponer la manifestada por el personal del IASB en el documento de análisis de efectos (IASB, 2016b) según la cual no debe haber impacto en el coste de la deuda y en los covenants, puesto que se piensa que habrá renegociaciones. Por otra parte, Demerjian (2011) y Paik, van der Laan Smith, Lee y Yoon (2015) sostienen que las deudas fuera del balance ya se tienen en cuenta en las negociaciones previas a fijar los covenants, por lo que un eventual cambio normativo debería ser inocuo. Coincide también el documento del IASB en señalar que puede haber un cambio en la forma de financiación, compra versus alquiler, en aquellos casos en los que la razón para tener un alquiler operativo era sacarlo del balance.

En definitiva, tras la aplicación de la NIIF 16, las empresas tendrán más deudas y activos en el balance, lo que generalmente conllevará un mayor importe de la ratio de endeudamiento y tal vez una reducción en la rentabilidad económica. Frente a lo anterior, que sugiere un empeoramiento "aparente" de la situación empresarial (no olvidemos que los compromisos de pago, aunque no estén reconocidos, existen), hay que contraponer la "mejora" en el EBITDA que el nuevo tratamiento del arrendamiento operativo conlleva. Efectivamente este indicador no incluye entre sus componentes los gastos financieros ni la amortización, por lo que, al sustituir el gasto por arrendamiento por la amortización y el interés, resultará un mayor EBITDA.

\section{Análisis empírico}

\subsection{Muestra}

La muestra inicial objeto de análisis está integrada por las empresas que componían el IBEX 35 en 2014, y que divulgaron información sobre arrendamientos operativos en la memoria. Estas empresas han sido consideradas en diversos trabajos, ya que representan un colectivo en el que se pueden identificar algunos de los temas más relevantes referidos a la información contable y financiera (Ortiz \& Marín, 2014; Reverte, 2009 y 2016). Se excluyen las entidades financieras y las empresas de seguros, lo que además de ser común en la literatura contable, dada la distinta interpretación de las ratios financieras, es especialmente frecuente cuando se analiza el impacto de la capitalización de los arrendamientos operativos - de hecho, como se ha indicado anteriormente, tan sólo se incluyen en EFRAG (2016). Debe tenerse en cuenta que, la inclusión de los sectores financiero y de seguros puede subestimar el impacto relativo, ya que en ellos las entidades además de ser de gran tamaño suelen tener arrendamientos operativos poco materiales. Adicionalmente resulta necesario eliminar aquellas empresas que no informan sobre arrendamientos operativos en la memoria, por lo que la muestra queda reducida a 20 empresas. Se ha hecho el estudio de simulación para el periodo de 4 años comprendido entre 2010 y 2013, ambos inclusive.

La información necesaria para estimar los arrendamientos operativos se ha obtenido manualmente de las memorias, mientras que los datos adicionales financieros y de mercado de la base de datos Sistema de Análisis de Balances Ibéricos (SABI). Según requiere la NIC 17, deben revelarse los pagos mínimos futuros por 
arrendamientos operativos clasificados en los correspondientes a un año, entre uno y cinco años y a partir de cinco años. Estos datos permiten conocer una primera aproximación del montante de deuda no reconocida, pero dado que la cifra no está descontada, resulta sobrevalorada.

Con la finalidad de obtener una magnitud representativa del valor de la deuda no reconocida es necesario actualizar los pagos futuros. Para ello se ha empleado el método de capitalización constructivo, que muestra el efecto de la capitalización sobre el activo y el pasivo, y además proporciona el impacto sobre el patrimonio neto. Este método fue desarrollado por Imhoff, Lipe y Wright (1991) y ha sido aplicado con frecuencia en esta literatura (Imhoff, et al., 1993; Imhoff, Lipe \& Wright, 1997; Durocher, 2008; Fülbier et al., 2008; Fitó et al., 2013; Giner \& Pardo, 2017). En la estimación se tiene en cuenta el momento inicial del contrato de arrendamiento operativo, de forma que se valora como si de un arrendamiento financiero se tratase. En el subapartado siguiente exponemos cómo opera este método.

También es frecuente utilizar el método del factor, que consiste en multiplicar por un coeficiente (usualmente 8) las cuotas de arrendamiento que se incluyen en la cuenta de pérdidas y ganancias (Imhoff et al., 1993; Ely, 199 5; Beattie, Goodacre \& Thomson, 2000; Bennett \& Bradbury, 2003). En tal caso el activo y el pasivo aumentan por igual, sin que haya ningún impacto en el neto patrimonial. Este procedimiento es utilizado como análisis de sensibilidad en este trabajo.

\subsection{Método de capitalización constructivo}

La implementación de este método requiere introducir ciertas hipótesis simplificadoras, siguiendo a Imhoff et al. (1991) y a Fülbier et al. (2008), asumimos las siguientes: 1) Al inicio de cada contrato, el valor en libros del activo arrendado es igual al valor del pasivo por arrendamiento; 2) al final del arrendamiento, los valores contables del activo y el pasivo son cero; 3) se utiliza el método lineal para amortizar los activos; 4) todos los pagos por arrendamiento se hacen al final del año; 5) los pagos por arrendamiento son constantes; y 6) los pagos por arrendamiento mínimos se distribuyen en cinco categorías de contratos con diferentes vidas (de un año a cinco o más años).

Puesto que los pagos mínimos futuros por arrendamiento operativo (PMARO) no se divulgan desglosados por año (excepto los del primero), es necesario aislar los pagos por año. Para los pagos de dos a cinco años, se asume un modelo de degresión geométrico en el cual los pagos por arrendamiento disminuyen a una tasa constante; el pago de cualquier año $\left(P M A R O_{t+1}\right)$ se obtiene multiplicando el pago del año anterior $\left(P M A R O_{t}\right)$ por el factor decreciente $(f d)$, como sigue:

$$
P M A R O_{t+1}=P M A R O_{t} \times f d
$$

por lo que el factor decreciente se obtiene de la siguiente expresión:

$$
P M A R O_{2-5}=P M A R O_{1} \times f d^{1}+P M A R O_{1} \times f d^{2}+P M A R O_{1} \times f d^{3}+P M A R O_{1} \times f d^{4}
$$

o lo que es lo mismo:

$$
P M A R O_{2-5}=\sum_{(t=1)}^{4} P M A R O_{1} \times f d^{t}
$$

La expresión anterior produce unos pagos por arrendamiento decrecientes, lo cual es consistente con tener varios contratos con diferentes duraciones (y no sólo un contrato). Teniendo en cuenta estos aspectos, y siguiendo a Fülbier et al. (2008) dividimos los PMARO en cinco categorías de contratos con diferentes vidas restantes (un año hasta cinco años o más) y obtenemos el valor actual de cada grupo. Para separarlos calculamos la diferencia entre los $P M A R O$ en dos años consecutivos $\left(P M A R O_{t}-P M A R O_{t+1}\right)$, lo que representa el contrato que finaliza cada año. En el último período de pagos anuales, dividimos el pago agregado después del año cinco en pagos anuales iguales al quinto grupo $\left(P M A R O_{5+} / P M A R O_{5}\right)$, lo que nos permite aproximar el número de años que restan de cuotas a pagar. Esto es consistente con la suposición general de que los pagos por arrendamiento de los contratos son constantes. Debemos indicar que utilizamos la información proporcionada 
en la memoria en la mayor medida posible, por ello cuando la empresa divulga los pagos anuales desagregados, utilizamos esta información. Para aquellas empresas que divulgan los PMARO en períodos más cortos, hemos agrupado los pagos en los períodos estándar, para implementar el método de manera uniforme.

Una vez estimados los pagos futuros, es necesario utilizar una tasa de descuento para determinar el valor actual. Si bien la más adecuada es la implícita en los arrendamientos, esta información solamente la ofrecen dos empresas de la muestra. Tras analizar las distintas posibilidades que ofrece la literatura: establecer un tipo de interés fijo (Imhoff et al., 1991), utilizar el obtenido al dividir los gastos financieros por el beneficio antes de intereses e impuestos (en adelante, EBIT) añadiéndole una tasa libre de riesgo (Fitó et al., 2013), emplear el que resulta de dividir los gastos financieros entre la deuda financiera (Imhoff et al., 1991, 1997) y utilizar la tasa de descuento aplicada a las provisiones (Fülbier et al., 2008), nos hemos decantado por esta última, ya que capta las peculiaridades de la empresa, y se encontraba disponible en la mayor parte de las empresas consideradas. Como hacen estos autores, para las 5 empresas de las que no disponíamos de esta información, hemos aplicado la mediana del resto de empresas que sí revelan esta tasa (4.36\%). Tras realizar los cálculos oportunos, el tipo de interés aplicado oscila entre el 2.80 y el $8.51 \%$.

Respecto a la valoración del activo, si bien es igual al pasivo al inicio del arrendamiento, en cualquier otro momento difiere. Así, el valor del activo es una función del valor actual de los PMARO al inicio del arrendamiento $\left(P M A R O_{V T}\right)$ y la relación entre la vida restante del contrato de arrendamiento $\left(V_{R}\right)$ y vida total del $\operatorname{mismo}\left(V_{\mathrm{T}}\right)$ :

$$
\text { Valor activo }=P M A R O_{V T} \times \frac{V_{R}}{V_{T}}
$$

Dado que el pasivo por arrendamiento al cierre del ejercicio es igual al valor actual de los PMARO durante la vida útil restante $\left(P M A R O_{V R}\right)$, la relación de cualquier activo por arrendamiento con el pasivo correspondiente en cualquier momento durante el período del contrato se determina por:

$$
\frac{V_{R}}{V_{T}} \times \frac{P M A R O_{V T}}{P M A R O_{V R}}
$$

lo que es lo mismo:

$$
\frac{V_{\mathrm{R}}}{V_{T}} \times \frac{1-(1+i)^{-V T}}{1-(1+i)^{-V \mathrm{R}}}
$$

Dado que no tenemos los PMARO totales, aplicamos la fórmula anterior y usamos el tipo de interés estimado. Además, como en las cuentas anuales no se revela la vida total del arrendamiento, para estimar el importe de los activos no registrados al aplicar el método constructivo asumimos que la proporción de vida de arrendamiento ya expirada $\left(V_{\mathrm{R}} / V_{\mathrm{T}}\right)$ es del 50\%, en línea con trabajos anteriores (Ely, 1995; Bennett \& Bradbury, 2003; Durocher, 2008; Fülbier et al., 2008). Debemos destacar que esta suposición tiene un efecto mínimo en los resultados del ejercicio, ya que la suma de los intereses y la amortización es muy similar al gasto por arrendamiento. No obstante, en un análisis de sensibilidad también consideramos el 60\%, como Fülbier et al. (2008) y Fitó et al. (2013), entre otros.

La capitalización tiene impacto en el impuesto diferido, y su importe se obtiene multiplicando la diferencia entre el activo y el pasivo por el tipo impositivo estimado. La diferencia entre ambas cantidades (diferencia entre el activo y el pasivo menos la disminución del impuesto diferido) es el importe por el que se verá reducido el patrimonio neto. El tipo impositivo se obtiene al dividir el gasto por impuesto sobre sociedades por el beneficio antes de impuestos (en adelante, BAI) del año correspondiente. En el caso que el BAI sea negativo o en ausencia de gasto por impuesto, el tipo impositivo que se ha empleado es el tipo impositivo aplicado en el ejercicio más próximo. 


\subsection{Impacto de la capitalización de los arrendamientos operativos}

Con anterioridad a calcular las nuevas ratios, se ha ajustado el valor del activo, pasivo y patrimonio neto por la capitalización de los arrendamientos operativos. La Tabla 1 muestra el importe de la deuda por arrendamiento operativo sin descontar (en la columna 1) y una vez descontada mediante el método constructivo (en la columna 2), para cada uno de los años de análisis. La diferencia entre ambos valores depende de la hipótesis asumida sobre el tipo de interés, entre otros aspectos. Comparando los datos en las columnas 1 y 2 , se puede comprobar que no se trata de una diferencia desdeñable, ya que las cifras sin descontar son alrededor de un 30\% mayores que las resultantes de aplicar el método constructivo (alcanzando el 36\% en 2013).

Según se expone en la columna 2, en cualquiera de los años, el monto global de deudas no contabilizadas sería de alrededor de 20 mil millones de euros, lo que supone de forma agregada un 4.81\% de aumento con respecto a la deuda reconocida en el balance (dato no tabulado), cifra superior a la señalada por el EFRAG (2016), que es de un 1.3\% (aunque hay que tener en cuenta, que en este dato está incluido el sector financiero, mientras que en nuestra muestra se ha excluido). Comparando el aumento en la deuda con el activo, tal y como hace el IASB, en nuestro análisis obtenemos un 3.3\% (dato no tabulado) menor que el 5.4\% que presenta ese informe (IASB, 2016b).

En la columna 4 de la Tabla 1 se incluye la deuda por arrendamiento financiero reconocida en balance (también obtenida de forma manual a partir de la memoria), pudiéndose observar que la derivada de los operativos excede considerablemente a la de los financieros, ya que es superior al doble de los arrendamientos financieros. Respecto a la proporción de financieros y operativos, la columna 3 presenta los porcentajes por año de la deuda por arrendamiento operativo respecto a la deuda por arrendamiento total que oscilan entre el $65 \%$ y el $69 \%$, cifras que se asimilan al 67\% proporcionado para 2005 por Barral et al. (2014). Estos datos podrían sugerir que se prefiere esta forma de financiación precisamente por la posibilidad que ofrece de escapar del control que ejerce el tener que figurar en el balance. Sin embargo, aún se encuentra sensiblemente por debajo del dato proporcionado en el estudio del EFRAG, en el que se indica que el volumen de arrendamientos operativos es 8.7 veces mayor que el de los financieros.

\begin{tabular}{|l|r|r|r|r|r|r|r|}
\cline { 2 - 8 } \multicolumn{1}{c|}{} & $\begin{array}{c}\text { ARO sin } \\
\text { descontar }\end{array}$ & $\begin{array}{c}\text { ARO } \\
\text { a valor actual }\end{array}$ & $\begin{array}{c}\text { AOR/ } \\
\text { ART }\end{array}$ & \multicolumn{1}{c|}{ ARF } & $\begin{array}{c}\text { ARF/A } \\
\text { RT }\end{array}$ & \multicolumn{1}{c|}{ ART } & $\begin{array}{c}\text { Gasto por } \\
\text { ARO }\end{array}$ \\
\hline $\mathbf{2 0 1 0}$ & $23,688,074$ & $18,713,864$ & $67 \%$ & $9,165,214$ & $33 \%$ & $27,879,078$ & $4,942,991$ \\
\hline $\mathbf{2 0 1 1}$ & $27,276,663$ & $20,979,412$ & $65 \%$ & $11,225,370$ & $35 \%$ & $32,204,782$ & $5,889,192$ \\
\hline $\mathbf{2 0 1 2}$ & $26,952,705$ & $21,321,158$ & $68 \%$ & $9,897,575$ & $32 \%$ & $31,218,733$ & $6,267,043$ \\
\hline $\mathbf{2 0 1 3}$ & $27,042,823$ & $19,860,848$ & $69 \%$ & $9,110,179$ & $31 \%$ & $28,971,027$ & $6,149,995$ \\
\hline Total & $\mathbf{1 0 4 , 9 6 0 , 2 6 5}$ & $\mathbf{8 0 , 8 7 5 , 2 8 3}$ & $\mathbf{6 7 \%}$ & $\mathbf{3 9 , 3 9 8 , 3 3 8}$ & $\mathbf{3 3 \%}$ & $\mathbf{1 2 0 , 2 7 3 , 6 2 0}$ & $\mathbf{2 3 , 2 4 9 , 2 2 1}$ \\
\hline
\end{tabular}

Nota: ARO son los compromisos de pago por arrendamiento operativo; ARF es la deuda por arrendamiento financiero; ART es la deuda total por arrendamiento. Las cifras están expresadas en miles de euros.

Tabla 1. Importe agregado de la deuda por arrendamiento operativo, financiero y total en términos absolutos y relativos por año

De forma gráfica se ilustran estos valores en la Figura 1, en el que también se visualiza la consistencia en los valores en los cuatro años examinados. Debemos precisar que en esta figura se representan los valores promedios de las empresas analizadas, por lo que los porcentajes que se indican en las líneas continuas no coinciden con los porcentajes que aparecen en la Tabla 1, en la que se han calculado de forma agregada.

También proporciona la Tabla 1 otra información de interés, el gasto por arrendamiento operativo, es decir el cambio en el EBITDA, que como se ha indicado mejora con el cambio normativo. En efecto, la última columna nos muestra un aumento anual agregado en 3 de los 4 años de más de 5 mil millones de euros en esta magnitud, lo que supone un $1 \%$ (dato no tabulado) del valor del activo agregado. 


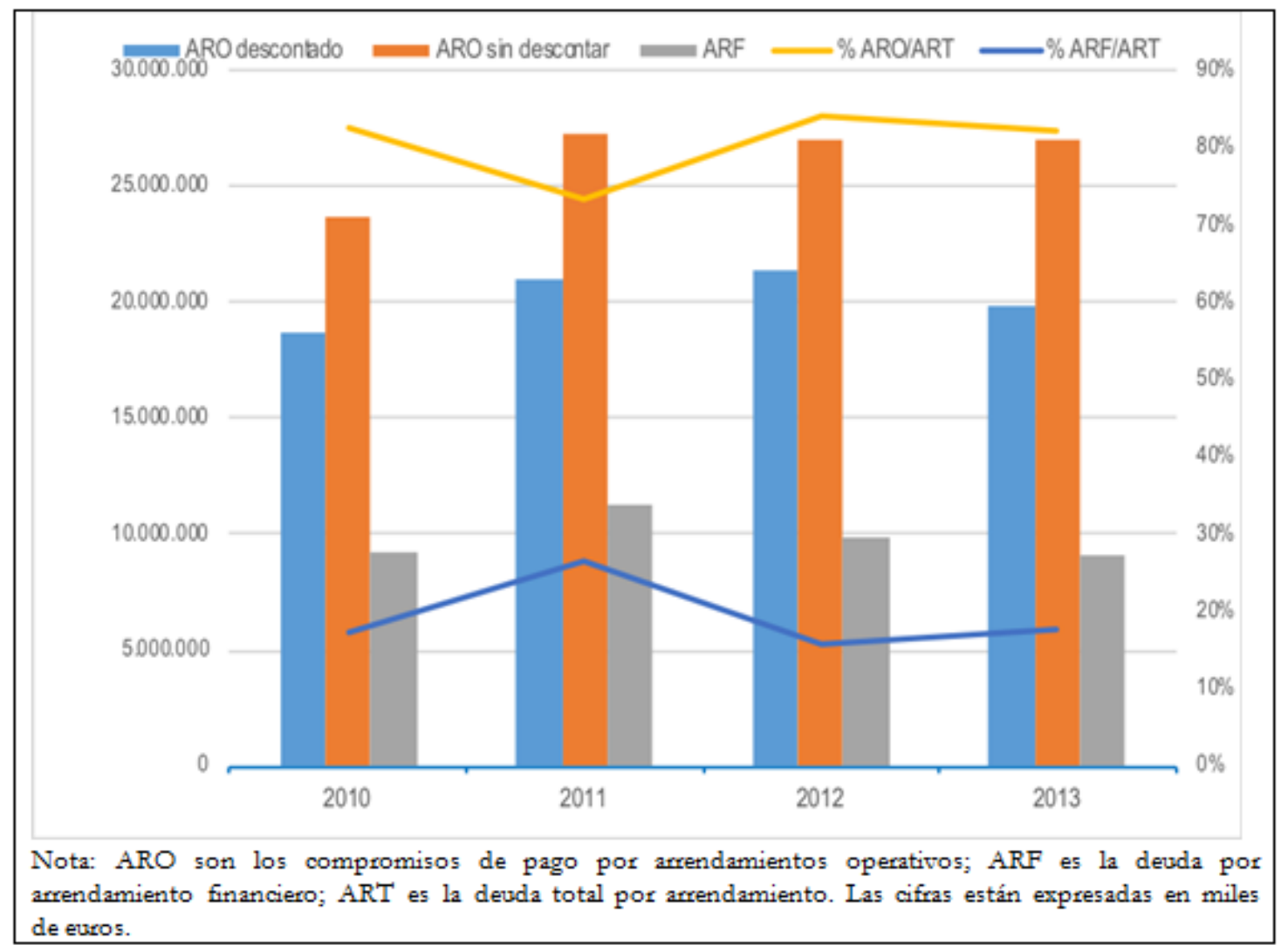

Figura 1. Valores absolutos y relativos de los arrendamientos operativos y financieros por año

La Tabla 2 muestra los estadísticos descriptivos correspondientes a las variaciones en el activo, pasivo y patrimonio neto consecuencia de la capitalización de los arrendamientos operativos, así como la variación en el EBITDA respecto al activo total. Se observa que el aumento de deuda es de un $7 \%$ en media y $2.2 \%$ mediana, si bien tiene una gran desviación típica, y de hecho el máximo alcanza el 67\%. En el informe de PwC se documenta un aumento de la deuda en mediana del 21\% para las empresas europeas consideradas (PwC, 2016). El aumento del activo es menor, $3.5 \%$ en media y $1.3 \%$ en mediana, siendo $21.3 \%$ el máximo. En lo que se refiere al patrimonio neto, la disminución en media es del $2.3 \%$, mientras que en mediana es solo del $0.5 \%$, aunque hay casos extremos, de forma que llega a disminuir en un $28.3 \%$. La ratio aumento en EBITDA dividido por el activo total nos muestra un aumento medio de $1.9 \%$ ( $0.9 \%$ en mediana), y alcanza un valor máximo de $13 \%$. Lo que nuevamente es consecuencia de la gran dispersión en los datos, esto es, del distinto previsible impacto del cambio contable a nivel de empresa.

\begin{tabular}{|l|r|r|r|r|r|r|r|r|}
\cline { 2 - 9 } \multicolumn{1}{c|}{} & \multicolumn{3}{c|}{ Variación en términos absolutos (miles de euros) } & \multicolumn{3}{c|}{ Variación en términos relativos (\%) } \\
\cline { 2 - 9 } \multicolumn{1}{c|}{} & ACTIVO & $\Delta$ PASIVO & $\Delta$ PATR. NETO & $\Delta$ EBITDA & $\Delta A / A T$ & $\Delta \mathrm{P} / P T$ & $\Delta P N / P N T$ & $\Delta E B I T D A / A T$ \\
\hline Mean & 888,329 & $1,010,941$ & $-122,612$ & 309,990 & $3.5 \%$ & $7.0 \%$ & $-2.3 \%$ & $1.9 \%$ \\
\hline StdDev & $1,601,073$ & $1,797,423$ & 209,820 & 394,967 & $5.3 \%$ & $14.3 \%$ & $5.0 \%$ & $3.0 \%$ \\
\hline Min. & 445 & 452 & $-1,057,647$ & 474 & $0.02 \%$ & $0.1 \%$ & $-28.3 \%$ & $0.02 \%$ \\
\hline Median & 233,542 & 268,577 & $-20,438$ & 133,000 & $1.3 \%$ & $2.2 \%$ & $-0.5 \%$ & $0.9 \%$ \\
\hline Max. & $8,020,092$ & $8,699,720$ & -7 & $1,663,967$ & $21.3 \%$ & $67.0 \%$ & $-0.0005 \%$ & $13.0 \%$ \\
\hline
\end{tabular}

Nota: $\Delta \mathrm{A} / \mathrm{AT}$ es la variación del activo por capitalización del arrendamiento operativo respecto al activo total; $\Delta \mathrm{P} / \mathrm{PT}$ es la variación del pasivo por capitalización del arrendamiento operativo respecto al pasivo total; $\Delta \mathrm{PN} / \mathrm{PNT}$ es la variación del patrimonio neto por capitalización del arrendamiento operativo respecto al patrimonio neto total; $\triangle \mathrm{EBITDA} / \mathrm{AT}$ es la variación en el EBITDA por capitalización del arrendamiento operativo respecto al activo total.

Tabla 2. Descriptivos de la variación por capitalización de los arrendamientos operativos por empresa 
Como se ha destacado antes, la metodología empleada para calcular el montante de deudas fuera del balance requiere asumir algunas hipótesis, referidas al tipo de interés para descontar las cuotas de arrendamiento y la vida útil restante del bien arrendado. En la Tabla 3 presentamos los descriptivos de las deudas por arrendamiento operativo respecto al activo total empleando varios escenarios. En la primera columna se presentan utilizando el tipo de descuento empleado por cada empresa para las provisiones; en la segunda columna se ha utilizado un tipo de interés fijo del $5 \%$, en la tercera del 10\%, y en la cuarta se ha manteniendo el tipo de interés inicial, pero se ha modificado la hipótesis sobre la vida útil restante del activo, de tal manera que la relación Vida Residual/Vida Total es del 60\%, en lugar del 50\%, que se utiliza en las columnas antes descritas. Finalmente, en la columna 5: "Sin descontar" aparece la suma de los pagos futuros por arrendamiento operativo indicados en la memoria, mientras que en la última columna se ha aplicado un método simple, pero también utilizado en el mundo de los negocios, el método del factor. Este procedimiento heurístico consiste en multiplicar el gasto por arrendamiento operativo anual por un multiplicador, siendo 8 el usualmente empleado en trabajos previos (Imhoff et al., 1993; Ely, 1995; Beattie et al., 2000; Bennett \& Bradbury, 2003). Beattie et al. (2000) se hacen eco de trabajos anteriores en los que se baraja un rango entre 6.9 y 10.2 para arrendamientos entre 10 y 20 años, por lo que consideramos que 8 es un multiplicador aceptable.

Si bien el utilizar un tipo de interés u otro no afecta en demasía a los estadísticos descriptivos (en las columnas 1 a 3), ni tampoco el alterar la vida útil restante (en la columna 4), las otras opciones producen cifras sensiblemente distintas. En particular aplicando el método del factor se concluye que el aumento en media será del 15.1\% (casi 4 veces más que con el constructivo), en mediana el 7.1\% (5 veces más), llegando el máximo a ser el 103.6\% del activo total. No debe sorprender que este método sobrevalore los activos y pasivos, ya que también sucede en trabajos referidos a EE.UU. (Imhoff et al., 1993), Reino Unido (Beattie et al., 2000) y Nueva Zelanda (Bennett \& Bradbury, 2003). Por otra parte, otra razón de esta sobrevaloración es que la duración de los contratos en nuestra muestra (18 años en mediana) es menor que en otros países como EE.UU.

\begin{tabular}{|c|c|c|c|c|c|c|}
\hline & $\begin{array}{c}\text { Método } \\
\text { constructivo }\end{array}$ & $\begin{array}{c}\text { Método } \\
\text { constructivo } \\
(i=5 \%)\end{array}$ & $\begin{array}{c}\text { Método } \\
\text { constructivo } \\
(i=10 \%)\end{array}$ & $\begin{array}{l}\text { Método constructivo } \\
\quad\left(V_{R} / V_{T}=60 \%\right)\end{array}$ & Sin descontar & $\begin{array}{l}\text { Método } \\
\text { del factot }\end{array}$ \\
\hline Media & $3.9 \%$ & $3.8 \%$ & $3.1 \%$ & $4.0 \%$ & $5.0 \%$ & $15.1 \%$ \\
\hline Desv. Tip. & $5.9 \%$ & $5.7 \%$ & $4.7 \%$ & $6.0 \%$ & $7.5 \%$ & $24.2 \%$ \\
\hline Mínimo & $0.02 \%$ & $0.02 \%$ & $0.02 \%$ & $0.02 \%$ & $0.02 \%$ & $0.2 \%$ \\
\hline Mediana & $1.4 \%$ & $1.4 \%$ & $1.2 \%$ & $1.4 \%$ & $1.9 \%$ & $7.1 \%$ \\
\hline Máximo & $23.1 \%$ & $22.6 \%$ & $19.2 \%$ & $23.3 \%$ & $27.5 \%$ & $103.6 \%$ \\
\hline
\end{tabular}

Nota: Método constructivo: supone aplicar un tipo de descuento específico para cada empresa según se explica en el apartado 5.2; Método constructivo (i=5\%): supone utilizar un tipo de interés fijo (5\%); Método constructivo (i=10\%): supone utilizar un tipo de interés fijo (10\%); Método constructivo $\left(V_{\mathrm{R}} / V_{T}=60 \%\right)$ : supone modificar la hipótesis sobre la vida útil restante del activo, de tal manera que la relación Vida Residual/Vida Total sea del 60\%; Sin descontar: es la suma de los pagos futuros por arrendamiento operativo divulgados; Método del factor: supone multiplicar el gasto por arrendamiento operativo anual por un factor de 8.

Tabla 3. Porcentaje de la deuda por arrendamiento operativo estimada con diferentes asunciones y métodos con respecto al activo total

Una vez computadas las variaciones derivadas de la inclusión de los nuevos elementos, en la tabla 4 presentamos una serie de ratios antes y después de la capitalización. Algunas de las cuales se tienen con frecuencia en cuenta en las restricciones de los contratos de préstamos. Las cinco primeras ratios evalúan el impacto en la presentación de las partidas en el balance (solvencia, endeudamiento, calidad de la deuda, liquidez e intensidad de la inversión), en las tres restantes se considera el efecto sobre la rentabilidad, tanto desde la perspectiva económica, la rotación y ROA, como financiera, ROE (return on equity). Por último calculamos la ratio market-tobook que sirve como indicador de la valoración que el mercado hace de la empresa, y capta las oportunidades de crecimiento de la misma. Al pie de la tabla se indica la forma precisa de cómputo de estas ratios.

Tras la obtención de las ratios, presentamos las medianas de los valores antes y después de la capitalización, ya que este estadístico está menos afectado por los valores extremos que la media, y calculamos su variación relativa. Finalmente, con objeto de determinar si las diferencias de estas ratios son estadísticamente significativas, 
aplicamos el test no paramétrico de Wilcoxon (habiéndose comprobado previamente que las variables no siguen una distribución normal).

\begin{tabular}{|l|r|r|r|r|}
\hline Ratio & \multicolumn{1}{|c|}{$\begin{array}{c}\text { Antes de } \\
\text { capitalización }\end{array}$} & $\begin{array}{c}\text { Después de } \\
\text { capitalización }\end{array}$ & Diferencia relativa & Wilcoxon test \\
\hline Solvencia & 1.405 & 1.395 & $-0.65 \%$ & $7.770^{* * *}$ \\
\hline Endeudamiento & 2.472 & 2.529 & $2.31 \%$ & -7.7 \\
\hline Calidad de la deuda & 0.445 & 0.422 & $-5.37 \%$ & $-1.13 \%$ \\
\hline Liquidez & 1.087 & 1.075 & $1.02^{\%} \%$ & $7.509^{* * *}$ \\
\hline Intensidad de la inversión & 0.689 & 0.696 & $-6.56 \%$ & $-7.770^{* * *}$ \\
\hline Rotación del activo no corriente & 0.988 & 0.923 & $-2.15 \%$ & $7.770^{* * *}$ \\
\hline ROA & 0.047 & 0.046 & $1.33^{*} \%$ & $6.777^{* * *}$ \\
\hline ROE & 0.106 & 0.107 & $0.71 \%$ & $-5.823^{* * *}$ \\
\hline Market-to-book & 1.446 & 1.456 & $-7.673^{* * *}$ \\
\hline
\end{tabular}

Nota: Solvencia se mide como activo total/pasivo total; Endeudamiento como pasivo total/patrimonio neto; Calidad de la deuda como pasivo a corto plazo/pasivo total; Liquidez como activo corriente/pasivo corriente; Intensidad de la inversión como activo no corriente/activo total; Rotación del activo no corriente como ventas netas/activo no corriente; ROA como EBIT/activo total; ROE como resultado neto/patrimonio neto; Market-to-book como capitalización total de mercado/patrimonio neto. Los valores de las ratios son la mediana de las empresas de la muestra.

Tabla 4. Impacto de la capitalización de los arrendamientos operativos sobre ratios financieras

Como se observa en la Tabla 4, todas las variaciones son estadísticamente significativas, tal cual sucede en Fitó et al. (2013) y Giner y Pardo (2017), entre otros. Las ratios que sufren un mayor impacto son la rotación de activo no corriente, la de calidad de la deuda, seguidas del endeudamiento y ROA. Para el resto, el impacto se sitúa próximo al 1\%. Conviene destacar que no todas las ratios resultan penalizadas, ya que la ratio de rentabilidad financiera (ROE) y la market-to-book mejoran (un $1.33 \%$ y un $0.71 \%$ respectivamente), ratios que son las que en última instancia reflejan la ganancia para los accionistas. También experimenta una mejoría notable la ratio calidad de la deuda (disminuye en 5.37\%), ya que la mayor parte del endeudamiento que se añade al balance es a largo plazo. Sin embargo, el endeudamiento, la solvencia, la liquidez, así como la rotación y la ROA resultan penalizados (el primero aumenta en un 2.31\%, y los demás se reducen, el impacto en la rotación es el 6.56\% y en la ROA el 2.15\%). Ello significa que algunas empresas podrían verse obligadas a renegociar las condiciones de sus préstamos, si estas ratios se hubieran incluido en los contratos de deuda sin haber "congelado" las prácticas contables a tener en cuenta para su cómputo; ciertamente en este caso, convendría iniciar las conversaciones lo antes posible para evitar sorpresas de última hora.

Dado que la literatura sugiere que no todos los sectores resultarán igualmente afectados por el cambio contable (EFRAG, 2016; IASB, 2016b; PwC, 2016), consideramos interesante realizar la comparación del impacto por sectores, sin embargo, dado el pequeño tamaño muestral, lo que seguidamente presentamos es más bien un análisis por empresa. Basándonos en la clasificación de la Bolsa de Madrid: Energía, Construcción e industria, Bienes de consumo, Servicios de consumo y Tecnología, hemos calculado el impacto como la variación media de las ratios de las empresas de cada sector, y en la Tabla 5 presentamos los resultados. No resulta sorprendente que sean las empresas de los sectores de Bienes de consumo y Servicios de consumo las que resultan más afectadas por el cambio contable, dado que como revela la literatura previa en estos sectores se utiliza con profusión este tipo de contratos. En conjunto, debemos destacar el impacto en las ratios de endeudamiento y rentabilidad económica (ROA). En las empresas de estos sectores, el endeudamiento aumenta en un 25\%, dado el aumento en el volumen de deudas reconocidas. También, la rotación y la ROA se reducen en aproximadamente un $11 \%$ y un 7\%, respectivamente, como consecuencia del aumento de activos que supone la capitalización. Sin embargo, el impacto de la capitalización sobre el neto patrimonial difiere entre ambos grupos de empresas, lo que afecta a los cambios en la ratio de solvencia, ROE y market-to-book. 


\begin{tabular}{|c|c|c|c|c|c|}
\hline Ratio & Energía & $\begin{array}{l}\text { Construcción e } \\
\text { industria }\end{array}$ & $\begin{array}{l}\text { Bienes de } \\
\text { consumo }\end{array}$ & $\begin{array}{l}\text { Servicios de } \\
\text { consumo }\end{array}$ & Tecnología \\
\hline Solvencia & $-1.1 \%$ & $-0.5 \%$ & $-10.2 \%$ & $-2.7 \%$ & $-1.4 \%$ \\
\hline Endeudamiento & $2.9 \%$ & $3.1 \%$ & $25.9 \%$ & $25.0 \%$ & $6.0 \%$ \\
\hline Calidad de la deuda & $-0.8 \%$ & $-0.7 \%$ & $-7.4 \%$ & $-6.0 \%$ & $-1.7 \%$ \\
\hline Liquidez & $-1.4 \%$ & $-0.8 \%$ & $-9.7 \%$ & $-4.4 \%$ & $-2.6 \%$ \\
\hline Intensidad de la inversión & $0.4 \%$ & $3.4 \%$ & $6.7 \%$ & $3.4 \%$ & $0.7 \%$ \\
\hline $\begin{array}{l}\text { Rotación del activo no- } \\
\text { corriente }\end{array}$ & $-1.6 \%$ & $-4.0 \%$ & $-11.8 \%$ & $-10.5 \%$ & $-3.5 \%$ \\
\hline ROA & $-1.1 \%$ & $-1.1 \%$ & $-6.8 \%$ & $-7.6 \%$ & $-2.9 \%$ \\
\hline ROE & $0.7 \%$ & $1.4 \%$ & $1.3 \%$ & $11.2 \%$ & $1.5 \%$ \\
\hline Market-to-book & $0.7 \%$ & $1.4 \%$ & $1.3 \%$ & $11.3 \%$ & $1.5 \%$ \\
\hline
\end{tabular}

Nota: Solvencia se mide como activo total/pasivo total; Endeudamiento como pasivo total/patrimonio neto; Calidad de la deuda como pasivo a corto plazo/pasivo total; Liquidez como activo corriente/pasivo corriente; Intensidad de la inversión como activo no corriente/activo total; Rotación del activo no corriente como ventas netas/activo no corriente; ROA como EBIT/activo total; ROE como resultado neto/patrimonio neto; Market-to-book como capitalización total de mercado/patrimonio neto. Los valores de los cambios en las ratios como consecuencia de la capitalización son la mediana de las empresas de la muestra.

Tabla 5. Impacto medio de la capitalización de los arrendamientos operativos sobre ratios financieras por sector

La Figura 2 capta el impacto en el EBITDA. De nuevo las empresas en los sectores minoristas son las más afectadas, si bien presentan un comportamiento diferenciado las de los sectores de Bienes de consumo y de Servicios de consumo. Datos no tabulados revelan que en el sector Bienes de consumo el gasto anual por arrendamiento es mucho mayor que en el de Servicios de consumo (principalmente debido a la empresa Inditex), aunque la deuda por arrendamiento operativo no es muy distinta en valores absolutos, ni tampoco con respecto al total del activo. Ello hace que el impacto en la ratio variación en el EBITDA/activo total suponga un aumento del 6.7\% en las empresas del sector Bienes de consumo, frente al 3.4\% en las de Servicios de consumo.

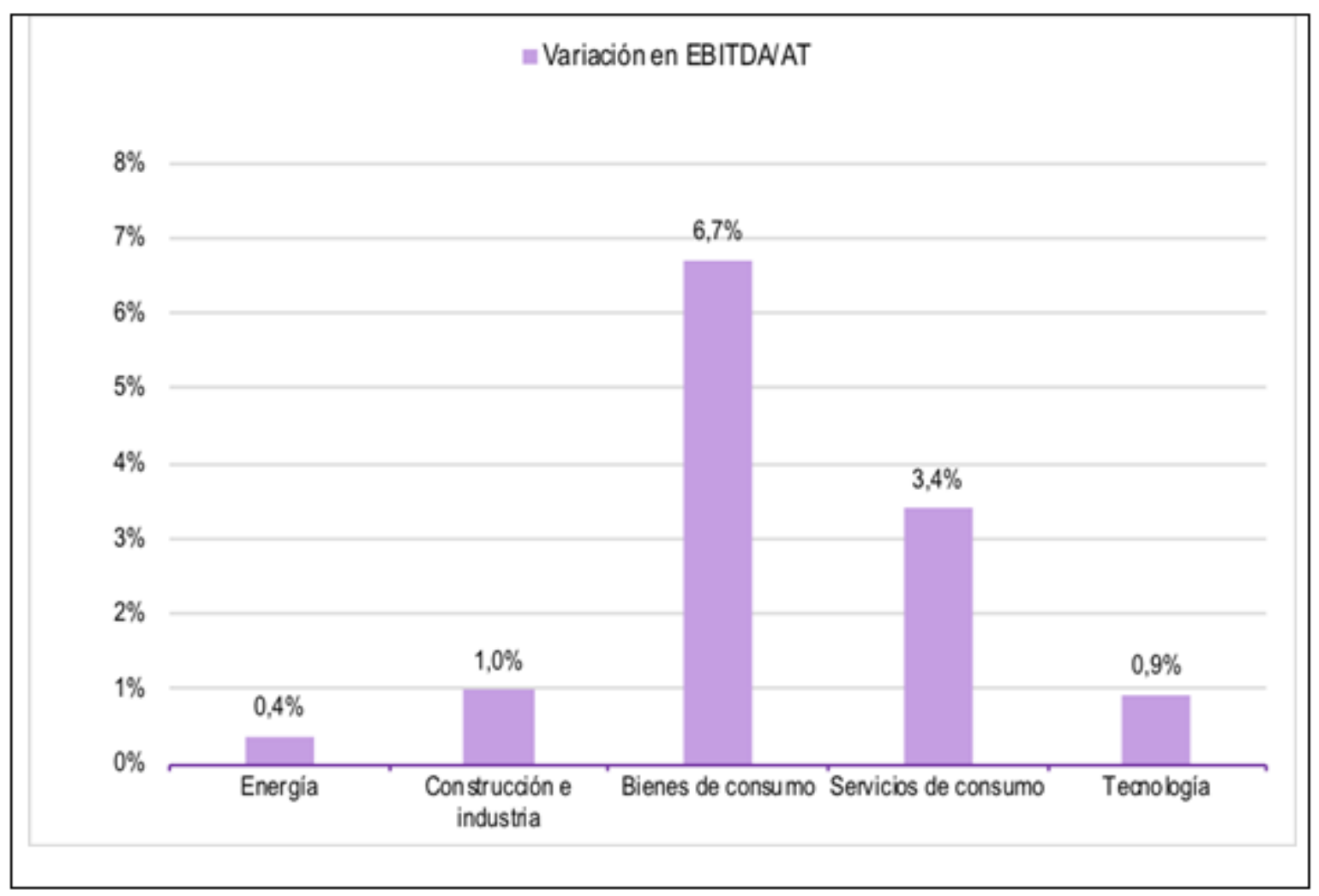

Figura 2. Efecto de la capitalización de los arrendamientos operativos por sector 


\subsection{Factores explicativos del cambio en el EBITDA}

Dada la importancia que los inversores y analistas atribuyen al EBITDA, hemos investigado los aspectos que explican el impacto de la norma en esta magnitud. El cambio en el EBITDA coincide con el gasto por arrendamiento operativo, por lo que cuantos más contratos de arrendamiento operativo tenga la empresa y mayor sea su importe, mejor será la imagen empresarial tras el cambio contable. Es, por lo tanto, un indicador de la incidencia de este tipo de arrendamiento en la empresa.

Basándonos en las explicaciones que la literatura ha proporcionado sobre este tipo de financiación, entre las que destaca la naturaleza de los activos directamente relacionada con el sector en el que opera la empresa (Smith \& Wakeman, 1985; Krishnan \& Moyer, 1994), establecemos una hipótesis sector. En efecto, cuanto mayor es la especificidad de los activos menor es la preferencia por el arrendamiento, ya que existen más costes de agencia (relacionados con la negociación y el control de los contratos), lo que hace más atractiva la opción de la propiedad plena. Por el contrario, cuando se trata de activos poco específicos (típicos en contratos cortos), tal cual sucede en sectores minoristas, se recurre más a los arrendamientos dado que en caso necesario resulta fácil deshacerse de los activos, que siguen siendo propiedad de los arrendadores. En definitiva, planteamos la siguiente hipótesis en forma alternativa:

\section{H1: Las empresas de los sectores minoristas experimentarán una mejoría del EBITDA mayor que las del resto de sectores.}

Seguidamente, nos referimos a la situación financiera de las empresas. Según postulan las investigaciones previas, las que se encuentran en una situación financiera delicada, tienen más deudas, y utilizan con más frecuencia este tipo de contratos (Smith \& Warner, 1979; Krishnan \& Moyer, 1994; Eisfeldt \& Rampini, 2009; Cornaggia, Franzen \& Simin, 2013). Proponemos la siguiente hipótesis, también en forma alternativa:

H2: Las empresas con una ratio de endeudamiento más elevada experimentarán una mejoría del EBITDA mayor que las que tienen una ratio menor.

Finalmente incluimos otra hipótesis que capta las oportunidades de crecimiento. Como señalan Graham, Lemmon y Schallheim (1998) a través del arrendamiento operativo se puede aliviar el problema de sustitución de activos, que es más frecuente en las empresas en crecimiento. En definitiva, la tercera hipótesis también en forma alternativa es:

H3: Las empresas con más oportunidades de crecimiento experimentarán una mejoría del EBITDA mayor que las que tienen menos oportunidades.

El modelo que empleamos es:

$$
\triangle E B I T D A / A T=a_{0}+a_{1} \text { Sector }+a_{2} \text { END }+a_{3} M / B+\alpha_{4} \text { Tamaño }+\varepsilon
$$

Donde: $\triangle E B I T D A / A T$ es la variación en el EBITDA dividida por el activo total; Sector es una variable indicador que toma el valor 1 , si la observación pertenece al sector de Bienes de consumo o de Servicios de consumo, y 0, en otro caso; END es el endeudamiento calculado como pasivo total/patrimonio neto; $M / B$ es la ratio market-to-book; Tamaño se mide como el logaritmo de las ventas netas. Las variables independientes se miden sin tener en cuenta el impacto de la capitalización de los arrendamientos operativos.

Para las tres variables explicativas (Sector, END y $M / B$ ) esperamos una relación positiva con el impacto en el EBITDA. Hemos introducido el tamaño de la empresa en el modelo (expresión 7) dado que es un control que habitualmente se incorpora en este tipo de análisis, pero no tenemos ninguna expectativa concreta respecto a su signo.

Utilizamos el procedimiento de Petersen (2009) para estimar los errores estándares de forma que sean robustos a la heteroscedasticidad, la correlación serial y transversal con un cluster bidimensional a nivel de empresa y año. Adicionalmente, se han calculado los coeficientes de correlación de Pearson para las variables utilizadas en el análisis multivariante, y los resultados, recogidos en la tabla 6, indican que las correlaciones entre las variables 
independientes no son elevadas. Asimismo hemos calculado el factor de inflación de la varianza de cada variable (FIV) y los resultados no sugieren problemas de multicolinealidad.

\begin{tabular}{|c|c|c|c|c|c|}
\hline Variables & $\Delta E B I T D A / A T$ & Sectot & END & $M / B$ & Tamaño \\
\hline$\triangle E B I T D A / T A$ & 1 & & & & \\
\hline Sector & $0.568 * * *$ & 1 & & & \\
\hline END & 0.127 & 0.007 & 1 & & \\
\hline$M / B$ & $0.570 * * *$ & $0.407 * * *$ & $0.512^{* * *}$ & 1 & \\
\hline Tamaño & 0.094 & $-0.249 * *$ & 0.008 & -0.143 & 1 \\
\hline
\end{tabular}

Nota: $\triangle E B I T D A / A T$ es la variación en el EBITDA dividida por el activo total; Sector es una variable indicador que toma el valor 1 si la observación pertenece al sector de Bienes de consumo o de Servicios de consumo y 0, en otro caso; END es el endeudamiento calculado como pasivo total/patrimonio neto; M/B es la ratio Market-to-book; Tamaño se mide como el logaritmo de las ventas netas.

*** $1 \%$ significatividad; ** 5\%; * $10 \%$.

Tabla 6. Coeficientes de correlación de Pearson

La Tabla 7 describe la clasificación sectorial de la muestra siguiendo los criterios de la Bolsa de Madrid. Puede observarse que el sector Construcción e industria domina la muestra, y el resto se distribuyen por igual, si bien a efectos de nuestro análisis lo relevante es que los sectores minoristas representan un 30\%. En la Tabla 8 se resumen los estadísticos descriptivos de las variables utilizadas en el modelo, estando la mayoría de las distribuciones sesgadas a la derecha.

\begin{tabular}{|l|r|r|}
\hline Sector & Obs. Empresa-año & Porcentage \\
\hline Energía & 12 & $15 \%$ \\
\hline Construcción e industria & 32 & $40 \%$ \\
\hline Bienes de consumo & 12 & $15 \%$ \\
\hline Servicios de consumo & 12 & $15 \%$ \\
\hline Tecnología & 12 & $15 \%$ \\
\hline Total & 80 & $100 \%$ \\
\hline
\end{tabular}

Nota: Clasificación según la Bolsa de Madrid.

Tabla 7. Clasificación sectorial

\begin{tabular}{|l|r|r|r|r|r|}
\hline Variables & \multicolumn{1}{c|}{ Media } & Mediana & Desviación Típica & \multicolumn{1}{c|}{ Min. } & \multicolumn{1}{c|}{ Max. } \\
\hline$\triangle E B I T D A / A T$ & 0.0189 & 0.0089 & 0.0303 & 0.0002 & 0.1295 \\
\hline Sector & 0.3000 & 0.0000 & 0.4611 & 0.0000 & 1.0000 \\
\hline END & 4.6667 & 2.4718 & 8.1467 & 0.2118 & 63.2701 \\
\hline$M / B$ & 3.1576 & 1.4459 & 4.4833 & 0.1080 & 23.0454 \\
\hline Tamaño & 15.8617 & 15.9958 & 1.4095 & 13.3258 & 18.1009 \\
\hline
\end{tabular}

Nota: $\triangle E B I T D A / A T$ es la variación en el EBITDA dividida por el activo total; Sector es una variable indicador que toma el valor 1 si la observación pertenece al sector de Bienes de consumo o de Servicios de consumo y 0, en otro caso; END es el endeudamiento calculado como pasivo total/patrimonio neto; $M / B$ es la ratio Market-to-book; Tamaño se mide como el logaritmo de las ventas netas.

Tabla 8. Estadísticos descriptivos de las variables

En la Tabla 9 exponemos los resultados del modelo de regresión multivariante. Dado que las variables Sector y $M / B$ son significativas, se rechazan las dos hipótesis nulas, lo que confirma la influencia del sector y la ratio $M / B$ con los signos esperados en la mejora en el EBITDA, con una significatividad del $10 \%$ y del $1 \%$, respectivamente. Las empresas que pertenecen a los sectores de consumo y que tienen una mayor valoración en el mercado, lo que se relaciona con unas expectativas de crecimiento mayores, mejoran más esa magnitud. Respecto a la variable de control, Tamaño, su significatividad y signo positivo, nos permiten concluir que también las empresas más grandes presentarán un mayor incremento en el EBITDA; sin embargo, no podemos rechazar la hipótesis nula 2, por lo que no podemos afirmar que el endeudamiento tenga influencia en el cambio esperado 
de dicha magnitud. El coeficiente de determinación ajustado del 51.3\% sugiere que el modelo tiene una buena capacidad explicativa.

\begin{tabular}{|c|c|c|}
\hline & $\begin{array}{c}\text { Signo } \\
\text { esperado }\end{array}$ & $\begin{array}{l}\text { Coeficiente } \\
\text { (estadítico } t)\end{array}$ \\
\hline Constante & $?$ & $\begin{array}{r}-0.0949^{*} \\
(-1.828)\end{array}$ \\
\hline Sector & $(+)$ & $\begin{array}{r}0.0297^{*} \\
(1.804)\end{array}$ \\
\hline$E N D$ & $(+)$ & $\begin{array}{l}-0.0005 \\
(-0.988)\end{array}$ \\
\hline$M / B$ & $(+)$ & $\begin{array}{r}0.0032^{* * * *} \\
(3.209)\end{array}$ \\
\hline Tamaño & $(+/-)$ & $\begin{array}{r}0.0061^{*} \\
(1.908)\end{array}$ \\
\hline $\mathrm{R}^{2}$ ajuntado & & 0.513 \\
\hline \multicolumn{3}{|c|}{$\begin{array}{l}\text { Nota: *** } 1 \% \text { significatividad; } * * 5 \% ; * 10 \% \text {. } \\
\text { Variable dependiente: } \triangle E B I T D A / A T \text { es la variación en el EBITDA } \\
\text { dividida por el activo total. } \\
\text { Variables independientes: Sector es una variable indicador que toma el } \\
\text { valor } 1 \text { si la observación pertenece al sector de Bienes de consumo o de } \\
\text { Servicios de consumo y } 0 \text {, en otro caso; END es el endeudamiento } \\
\text { calculado como pasivo total/patrimonio neto; } M / B \text { es la ratio Market- } \\
\text { to-book: Tamaño se mide como el logaritmo de las ventas netas. }\end{array}$} \\
\hline
\end{tabular}

Tabla 9. Análisis de regresión multivariante

Como análisis de robustez, hemos replicado la regresión utilizando otros subrogados para las variables independientes. En particular, la variable END se ha calculado como pasivo total/activo total; la variable Sector se ha separado en cada uno de los sectores recogidos en la Tabla 7; y la variable Tamaño se ha medido como el logaritmo del activo total y con el de la capitalización de mercado. Los resultados obtenidos son básicamente consistentes con los reportados.

\section{Conclusiones}

La información que las empresas del IBEX 35 proporcionan en la memoria sobre los compromisos de pago por arrendamientos operativos se toma como base para cuantificar ex ante el impacto de la aplicación de la NIIF 16, aspecto que constituye el objetivo principal del presente trabajo. Se ha empleado el método de capitalización constructivo para estimar los activos y pasivos no reconocidos en balance según la norma actualmente en vigor. Los resultados revelan que la cuantía global de deudas no contabilizadas es de alrededor de 20 mil millones de euros, lo que supondrá un aumento del $4.81 \%$ con respecto a la deuda reconocida en el balance. No obstante lo anterior, debemos matizar que los resultados obtenidos en este y otros trabajos están condicionados por la metodología de cálculo de los elementos fuera del balance. Mediante el análisis de sensibilidad realizado comprobamos que utilizar un tipo de interés u otro no afecta de forma importante a los estadísticos descriptivos, ni tampoco modificar la asunción sobre la vida útil restante. Si bien utilizar el método del factor o no descontar el pasivo sí conduce a cifras sensiblemente distintas. En particular el método del factor hace que el aumento de las deudas en media sea casi 4 veces mayor que con el método constructivo. Estos resultados pueden entenderse como un "alivio" para ciertos usuarios no sofisticados que, al aplicar procedimientos simples, pueden llegar a creer que las deudas reales son mucho mayores que las que finalmente aflorarán.

Seguidamente se ha contrastado si el cambio en una serie de magnitudes y ratios financieras, algunas frecuentemente incluidas como restricciones en los contratos de deuda (covenants), es estadísticamente significativo. Los resultados sugieren que la NIIF 16 afecta de forma significativa a las magnitudes financieras, y en particular a la rotación del activo no corriente y la calidad de la deuda, seguidas del endeudamiento y la ROA. 
Debemos insistir en que no todas las ratios son penalizadas, ya que la ratio de rentabilidad financiera (ROE) y la market-to-book mejoran. Por otra parte, evidenciamos que hay diferencias sectoriales destacables. No resulta sorprendente que sean las empresas de los sectores de Bienes de consumo y Servicios de consumo las que resultan más afectadas por el cambio contable, dado que en estos sectores se utiliza con profusión este tipo de contratos.

A pesar de que al igual que otros trabajos, nuestros resultados evidencian que las ratios resultan significativamente afectadas por la capitalización, ello no supone necesariamente que vayan a producirse incumplimientos en los covenants al aplicar la NIIF 16. Esto se justifica por diversos motivos: i) las restricciones actuales podrían tener en consideración la información fuera del balance y se ajustan las ratios con dicha información (por ejemplo como se ha hecho en este trabajo o mediante algún otro procedimiento alternativo), ii) las restricciones establecidas "congelan las prácticas contables" que sirven como base para hacer los cálculos de las mismas, y además iii) el periodo de implementación de 3 años que establece el IASB es suficiente para entender los efectos del cambio y en consecuencia alterar los límites establecidos. A pesar de todo, si la inclusión en el balance aportase información desconocida, que revelase un mayor riesgo, es razonable suponer que tendrán lugar renegociaciones en las cláusulas.

Como se ha indicado anteriormente, ciertas magnitudes mejoran al aplicar la nueva normativa, y en concreto el EBITDA que excluye de su cómputo tanto la amortización como los intereses. En el estudio encontramos que las empresas más grandes, que tienen una mayor valoración en el mercado y pertenecen a los sectores de consumo mejoran más esa magnitud.

Concluimos este trabajo exponiendo sus implicaciones y limitaciones, así como posibles líneas de investigación en el futuro. Entendemos que conocer el cambio contable debe ayudar a entender el "empeoramiento" y la "mejora" en las magnitudes financieras. La empresa no cambia al aplicar la nueva norma, pero sí ofrece una mayor transparencia que debe ayudar a tomar mejores decisiones, si es que antes se ignoraban los riesgos o no se valoraban debidamente. También creemos que puede servir para iniciar renegociaciones de deuda, si inicialmente fueron ignorados los riesgos o si se incorporaron reglas mecánicas que pueden ser incumplidas. Respecto a las limitaciones, no cabe duda que el número de empresas es reducido, lo que supone ciertas cautelas en la generalización de los resultados. Aunque el método empleado para la capitalización exige introducir algunas hipótesis para su implementación, mediante los test de sensibilidad creemos haber aumentado la robustez de nuestras conclusiones. Debemos señalar que en este trabajo no se ha pretendido detectar todos los posibles impactos de la nueva forma de contabilizar los arrendamientos operativos, y en concreto se han excluido los aspectos de valoración y la determinación de los costes de implementación, que en algunos casos podrían ser elevados. Finalmente nos referimos a las líneas de investigación que podrían surgir tras la adopción de la NIIF 16. Desde nuestro punto de vista, el análisis ex post tanto del posible cambio de comportamiento de las empresas con respecto a los arrendamientos operativos, como de las decisiones de los usuarios constituyen nuevas oportunidades de investigación de gran interés.

\section{Agradecimientos}

Los autores agradecen la asistencia de Raquel Cancho en la obtención de los datos y los valiosos comentarios de los dos revisores.

\section{Declaración de conflictos de interés}

Los autores no han declarado posibles conflictos de interés por lo que respeta a la investigación, la autoría y/o la publicación de este artículo.

\section{Financiación}

El autor o autores no recibieron ningún soporte financiero para la investigación, la autoría y/o la publicación de este artículo. 


\section{Referencias}

Abdel-Khalik, A.R. (1981). The Economic Effects on Lessees of FASB Statement No. 13, Accounting for Leases. Stamford, CT.: FASB

Barral, A., Cordobés, M., \& Ramírez, J. (2014). Los arrendamientos operativos: impacto de su reconocimiento en los estados financieros y en la política de financiación de las compañías españolas y del Reino Unido. Revista de Contabilidad, 17(2), 212-223. https://doi.org/10.1016/j.rcsar.2014.08.001

Beattie, V., Edwards, K., \& Goodacre, A. (1998). The impact of constructive operating lease capitalisation on key accounting ratios. Accounting and Business Research, 28(4), 233-254.

https://doi.org/10.1080/00014788.1998.9728913

Beattie, V., Goodacre, A., \& Thomson, S. (2000). Recognition versus Disclosure: An Investigation of the Impact on Equity Risk using UK Operating Lease Disclosures. Journal of Business Finance \& Accounting, 27(9-10), 1185-1224. https://doi.org/10.1111/1468-5957.00352

Beatty, A., Liao, S., \& Weber, J. (2010). Financial reporting quality, private information, monitoring, and the leaseversus-buy decision. The Accounting Review, 85(4), 1215-1238. https://doi.org/10.2308/accr.2010.85.4.1215

Beneish, M., \& Press, E. (1993). Cost of Technical Violation of Accounting-Based Debt Covenants. The Accounting Review, 68, 233-257.

Bennett, B.K., \& Bradbury, M.E. (2003). Capitalizing non-cancelable operating leases. Journal of International Financial Management \& Accounting, 14(2), 101-114. https://doi.org/10.1111/1467-646X.00091

Bryan, S.H, Lilien, S., \& Martin, D.R. (2010). The Financial statement effects of capitalizing operating leases. Assessing the impact of the right-to-use model. The CPA Journal, August, 36-41.

Cooper, S. (2017). Implementation Update: IFRS 16 Leases. January 2017.

Cornaggia, K.J., Franzen, L.A., \& Simin, T.T. (2013). Bringing assets onto the balance sheet. Journal of Corporate Finance, 22(September), 345-360. https://doi.org/10.1016/j.jcorpfin.2013.06.007

Dechow, P.M., Ge, W., Larson, C.R., \& Sloan, R.G. (2011). Predicting material accounting misstatements. Contemporary Accounting Research, 28(1), 17-82. https://doi.org/10.1111/j.1911-3846.2010.01041.x

Deloitte (2011). How prepared is your organization to cope with these new standards? A Deloitte survey on the FASB's proposed changes to lease accounting standards. Retrieved from: http://www.iasplus.com/en/binary/usa/1102usleasessurvey.pdf (Last access date: December $3^{\text {rd }}$, 2015).

Demerjian, P.R. (2011). Accounting standards and debt covenants: Has the "balance sheet approach" led to a decline in the use of balance sheet covenants?. Journal of Accounting \& Economics, 52, 278-202. https://doi.org/10.1016/j.jacceco.2011.08.004

Duke, J.C., Hsieh, S.-J., \& Su, Y. (2009). Operating and synthetic leases: Exploiting financial benefits in the postEnron era. Advances in Accounting, 25(1), 28-39. https://doi.org/10.1016/j.adiac.2009.03.001

Durocher, S. (2008). Canadian evidence on the constructive capitalization of operating leases. Accounting Perspectives,7(3), 227-256. https://doi.org/10.1506/ap.7.3.2

EFRAG (2016). IFRS 16 Leases. Quantitative assessment of accounting impacts. July. Paper 08-02.

Eisfeldt, A., \& Rampini, A. (2009). Leasing, ability to repossess, and debt capacity. Review of Financial Studies, 22(4), 1621-1657. https://doi.org/10.1093/rfs/hhn026

Ely, K. (1995). Operating lease accounting and the market's assessment of equity risk. Journal of Accounting Research, 33, 397-415. https://doi.org/10.2307/2491495

FASB (Financial Accounting Standards Board) (1976). Accounting for Leases. Statement of Financial Accounting Standards No. 13. Stamford, CT: FASB. 
Fitó, M.Á., Moya, S., \& Orgaz, N. (2013). Considering the effects of operating lease capitalization on key financial ratios. Revista Española de Financiación y Contabilidad, 42(159), 341-369.

https://doi.org/10.1080/02102412.2013.10779750

Franz, D.R., HassabElnaby, H.R., \& Lobo, G.F. (2014). Impact of proximity to debt covenant violation on earnings management. Review of Accounting Studies, 19, 473-505. https://doi.org/10.1007/s11142-013-9252-9

Fülbier, R.U., Silva, J.L., \& Pferdehirt, M.H. (2008). Impact of lease capitalization on financial ratios of listed German companies. Schmalenbach Business Review, 60(2), 122-144. https://doi.org/10.1007/BF03396762

Gill de Albornoz, B., Rusanescu, S., \& Cabedo, P. (2017). Las nuevas normas contables de arrendamientos: Causas y potenciales efectos económicos. Revista de Contabilidad y Tributación, 406, 207-246.

Giner, B., \& Pardo, F. (2017). Operating lease decision and the impact of capitalization in a bank-oriented country. Applied Economics, 49(19), 1886-1900.

Goodacre, A. (2003). Operating lease finance in the UK retail sector. International Review of Retail, Distribution and Consumer Research, 13(1), 99-125. https://doi.org/10.1080/0959396032000065373

Graham, J.R., Lemmon, M.L., \& Schallheim, J.S. (1998). Debt, leases, taxes and the endogeneity of corporate tax status. Journal of Finance, 53, 131-162. https://doi.org/10.1111/0022-1082.55404

Imhoff, E.A., Lipe, R.C., \& Wright, D.W. (1991). Operating leases: impact of constructive capitalization. Accounting Horizons, 5(1), 51-63.

Imhoff, E.A., Lipe, R.C., \& Wright, D.W. (1993). The effects of recognition versus disclosure on shareholder risk and executive compensation. Journal of Accounting, Auditing and Finance, 8(4), 335-368.

https://doi.org/10.1177/0148558X9300800402

Imhoff, E.A., Lipe, R.C., \& Wright, D.W. (1997). Operating leases: Income effects of constructive capitalization. Accounting Horizons, 11(2), 12-32.

Imhoff, E.A., \& Thomas, J. (1988). Economic consequences of accounting standards: The lease disclosure rule change. Journal of Accounting and Economics, 10, 277-310. https://doi.org/10.1016/0165-4101(88)90006-7

IASC (International Accounting Standards Committe) (1997). Norma Internacional de Contabilidad. NIC 17 Arrendamientos.

IASB (International Accounting Standards Board) (2009). Preliminary Views. Leases. DP/2009/01. IFRS Foundation. March. London.

IASB (International Accounting Standards Board) (2010). Exposure Draft. Leases. ED/2010/9. IFRS Foundation. August. London.

IASB (International Accounting Standards Board) (2013). Exposure Draft. Leases. ED/2013/6. IFRS Foundation. May. London.

IASB (International Accounting Standards Board) (2016a). Leases. International Financial Reporting Standard No. 16. IFRS Foundation. March. London.

IASB (International Accounting Standards Board) (2016b). Effects Analysis. IFRS 16 Leases. IFRS Foundation. January. London.

Krishnan, V.S., \& Moyer, R.C. (1994). Bankruptcy costs and the financial leasing decision. Financial Management, 23, 31-42. https://doi.org/10.2307/3665737

Molina, H., \& Mora, A. (2015). Cambios conceptuales en la contabilidad de los arrendamientos: Retos normativos y académicos. Revista de Contabilidad, 18(1), 99-113. https://doi.org/10.1016/j.rcsar.2015.01.001

Mulford, C., \& Gram, M. (2007). The effects of lease capitalization on various financial measures: An analysis of the retail industry. Journal of Applied Research in Accounting \& Finance, 2(2), 3-13.

Nelson, A.J. (1963). Capitalising leases: The effect on financial ratios. Journal of Accountancy, 41, 49-58. 
Nikolaev, V.N. (2010). Debt Covenants and Accounting Conservatism. Journal of Accounting Research, 48(1), 137-175. https://doi.org/10.1111/j.1475-679X.2009.00359.x

Ortiz, E., \& Marín, S. (2014). Global Reporting Initiative (GRI) as recognized guidelines for sustainability reporting by Spanish companies on the IBEX 35: Homogeneity in their framework and added value in the relationship with financial entities. Intangible Capital, 10(5), 855-872. https://doi.org/10.3926/ic.492

Paik, D.G.H., van der Laan Smith, J.A., Lee, B.B., \& Yoon, S.W. (2015). The relation between accounting information in debt covenants and operating leases. Accounting Horizons, 29(4), 969-996. https://doi.org/10.2308/acch-51214

Petersen, M.A. (2009). Estimating standard errors in finance panel data sets: comparing approaches. Review of Financial Studies, 22(1), 435-480. https://doi.org/10.1093/rfs/hhn053

PwC (2016). A study on the impact of lease capitalization: IFRS 16: The new leases standard. February.

Reverte, C. (2009). Determinants of Corporate Social Responsibility Disclosure Ratings by Spanish Listed Firms. Journal of Business Ethics, 88, 351-366. https://doi.org/10.1007/s10551-008-9968-9

Reverte, C. (2016). Corporate social responsibility disclosure and market valuation: Evidence from Spanish listed firms. Review of Managerial Science, 10(2), 411-435. https://doi.org/10.1007/s11846-014-0151-7

Scott, D. (2017). Implementation Update: IFRS 16 Leases. January 2017.

Smith, C.W., \& Warner, J.B. (1979). Bankruptcy, Secured Debt, and Optimal Capital Structure: Comment. Journal of Finance, 34, 247-251. https://doi.org/10.1111/j.1540-6261.1979.tb02085.x

Smith, C.W., \& Wakeman, L.M. (1985). Determinants of corporate leasing policy. Journal of Finance, 40, 895-908. https://doi.org/10.1111/j.1540-6261.1985.tb05016.x

Intangible Capital, 2018 (www.intangiblecapital.org)

Article's contents are provided on an Attribution-Non Commercial 4.0 Creative commons International License. Readers are allowed to copy, distribute and communicate article's contents, provided the author's and Intangible Capital's names are included. It must not be used for commercial purposes. To see the complete license contents, please visit https://creativecommons.org/licenses/by-nc/4.0/. 